Studia Źródłoznawcze, t. LV

p-ISSN 0081-7147

e-ISSN 2451-1331

\title{
Piętnastowieczny rękopis Vita sancti Adalberti prior ze zbiorów biblioteki klasztornej w Herzogenburgu (z aneksem w sprawie niektórych lekcji kodeksu Klosterneuburg, Stiftsbibliothek 707)
}

Zarys treści: Artykuł zawiera omówienie kopii najstarszego Żywota św. Wojciecha z kodeksu o sygnaturze 57, należącego do biblioteki klasztoru Kanoników Regularnych w Herzogenburgu, w Dolnej Austrii. Zdaniem autora podstawą omawianej kopii jest zachowany do dziś rękopis Klosterneuburg, Stiftsbibliothek, cod. 707, k. 107r-119v.

Abstract: The article discusses a copy of Vita prior s. Adalberti in codex (no. 57) from the collection of the library of the Canons Regular Priory at Herzogenburg, Lower Austria. The author claims that the discussed copy is based on an extant manuscript: Klosterneuburg, Stiftsbibliothek, cod. 707, fols. 107r-119v.

Słowa kluczowe: Vita sancti Adalberti prior, rękopis, XV w., Erhart z Weitra, Herzogenburg, Stiftsbibliothek, cod. 57; Klosterneuburg, Stiftsbibliothek, cod. 707

Keywords: Vita sancti Adalberti prior, manuscript, $15^{\text {th }}$ century, Erhart von Weitra, Herzogenburg, Stiftsbibliothek, cod. 57, Klosterneuburg, Stiftsbibliothek, cod. 707

Położony w Dolnej Austrii, ok. 50 km (w linii prostej) na zachód od Wiednia, klasztor Kanoników Regularnych w Herzogenburgu może się poszczycić nie tylko dawną, sięgającą XIII stulecia historią i monumentalną barokową architekturą, lecz także cennym księgozbiorem obejmującym m.in. kolekcję średniowiecznych kodeksów rękopiśmiennych ${ }^{1}$. Zachował się wśród nich stosunkowo niewielkich rozmiarów (277 kart o wysokości ok. 29,5 cm, szerokości ok. 21,5 cm), oprawny w czerwoną skórę kodeks papierowy o sygnaturze $57^{2}$. Podobnie jak inne tzw. rękopisy zbiorcze (vel klocki) powstał on

\footnotetext{
${ }^{1}$ W XIII w. do Herzogenburga przeniósł się kanonicki konwent z pobliskiego St. Georgen an der Traisen. Zwięzły rys historii klasztoru daje np. W. Payrich, Herzogenburg, w: Die bestehenden Stifte der Augustiner-Chorherren in Österreich, Südtirol und Polen, red. F. Röhrig, Klosterneuburg-Wien 1997, s. 29-98; por. też ostatnio: 900 Jahre Stift Herzogenburg. Aufbrüche - Umbrüche - Kontinuität. Tagungsband zum wissenschaftlichen Symposium vom 22.-24. September 2011, red. G. Katzler, V. Zimmerl-Panagl, Innsbruck 2013. W sprawie klasztornego księgozbioru zob. prace cyt. w przyp. następnym.

${ }^{2}$ Księga doczekała się kilku - różnej objętości i precyzji - opisów inwentarzowych: G. Winner, Katalog der Handschriften der Stiftsbibliothek Herzogenburg, St. Pölten 1978 [mszp.], s. 70-72, <http://manuscripta.at/diglit/winner_1978_1/0072> [dostęp: 30.01.2016]; H. Mayo, Descriptive Inventories of Manuscripts Microfilmed for the Hill Monastic Manuscript Library. Austrian Libraries, t. 3: Herzogenburg, Collegeville (Minnesota) 1985, s. 193-198 (por. <http://www.vhmml.us/ research2014/catalog/detail.asp?MSID=25140> [dostęp: 26.01.2016]); F. Lackner, Datierte Handschriften in niederösterreichischen Archiven und Bibliotheken bis zum Jahre 1600, Katalog der datierten Handschriften in lateinischer Schrift in Österreich, t. 8, Wien 1988, cz. 1, s. 47, nr 30; Kurzinventar der illuminierten Handschriften bis 1600 und der Inkunabeln in der Bibliothek des Augustiner-Chorherrenstiftes Herzogenburg in Niederösterreich, Version 1a (August 2009), oprac. A. Tif, M. Roland, M. Theisen, A. Haidinger, <http://www.univie.ac.at/paecht-archiv-wien/ki/hzbg/hzbg_hss_webbilder/
} 
w wyniku oprawienia razem składek rozmaitej proweniencji, mieszczących teksty o różnej tematyce, spisane przez wielu skrybów. Treść księgi przedstawia się w istocie w sposób aż nadto różnorodny. Sąsiadują tu ze sobą m.in. fragment komentarza do Sentencji Piotra Lombarda Henryka Tottinga z Oyta, Manipulus curatorum Gwidona z Montrocher, oparta na dziele Wilhelma Duranda Exposicio misse, teksty modlitw w języku niemieckim, wreszcie utwory hagiograficzne ${ }^{3}$. Zwarty zespół tych ostatnich, spisany jedną ręką, zajmuje ostatnich 6 składek kodeksu (k. 211r-277v ${ }^{4}$. Pośród kilkunastu prac znalazła się także (k. 235v-244v) tzw. cesarska („A”) redakcja najstarszego żywota św. Wojciecha. Ponieważ w dotychczasowych badaniach nad Vita prior ta jej kopia nie została uwzględniona (informacji o niej próżno szukać w którejkolwiek z istniejących edycji), rodzą się oczywiste pytania o okoliczności jej powstania $\mathrm{i}$ właściwe jej miejsce $\mathrm{w}$ rękopiśmiennej tradycji dzieła ${ }^{5}$.

Ze względu na zbiorczy charakter kodeksu herzogenburskiego oraz zarysowaną właśnie wąską tematykę komunikatu, nie ma potrzeby silić się w tym miejscu na pełniejszy, niż sporządzone do tej pory, inwentarzowy opis całego zabytku. Wystarczy poprzestać na charakterystyce wspomnianych, końcowych jego składek. Tworzą one wyraźnie osobną całość. Należy przypuszczać, że pierwotnie - tj. zanim jeszcze do pracy przystąpił introligator, który na trwałe połączył wszystkie części obecnego kodeksu - stanowić miały zalążek innej, z niewiadomych powodów nigdy nieukończonej książki ${ }^{6}$. Przemawia za tym już sam fakt, że składki te mają własną, niezależną od pozostałych numerację: na ostatniej stronicy każdej z nich, u dołu, po środku, wpisano czerwienią kolejne arabskie cyfry od 1 (k. 222v) do 6 (k. 277v). Kustoszom tym towarzyszą niekiedy - umieszczone po prawej stronie, a zachowane w całości lub części (wskutek obcięcia przy oprawie) - reklamanty ${ }^{7}$ Stronice owych sześciu składek zapisano dość jednorodna gotycką bastarda ${ }^{8}$, którą zgodnie z zaproponowana nie tak dawno typologia gotyckiego pisma książkowego trzeba by określić mianem cursiva libraria, względnie cursiva currens ${ }^{9}$. Tekst na każdej ze stron podzielono na dwie kolumny o liczbie wierszy oscylującej wokół 40.

Jak wspomniano, finalna część rękopisu z Herzogenburga mieści niewielkie legendarium ${ }^{10}$. Porządek, w jakim wpisano poszczególne utwory nie odpowiada układowi kalendarza liturgicznego, nie widać też żadnej innej zasady, która by go tłumaczyła ${ }^{11}$. Niemal całą pierwszą składkę (k. 211r-222r)

index_hzbg_hss_1_bis_89.html\#cod_> [dostęp: 28.12.2015]. Ten ostatni oferuje kilkanaście zdjęć wybranych stronic i oprawy kodeksu (którą redaktorzy uważają za średniowieczną). W przedstawionej poniżej charakterystyce końcowych partii rękopisu wykorzystano zarówno spostrzeżenia autorów wymienionych inwentarzy, jaki i własne, poczynione podczas autopsji księgi, latem $2014 \mathrm{r}$

3 Zawartość kodeksu najpełniej opisują: G. Winner, Katalog, s. 70-72; H. Mayo, Descriptive Inventories, s. $193-198$.

${ }^{4}$ Są to wszystko seksterniony, ostatni z nich pozbawiono jednak pięciu kart; F. Lackner, Datierte Handschriften, s. 47. Końcowe stronice ostatniej składki, tj. k. 276v-277v, pozostawiono pierwotnie puste.

${ }^{5}$ Podstawową edycją cesarskiej redakcji Żywota pozostaje: S. Adalberti Pragensis episcopi et martyris vita prior, wyd. J. Karwasińska, w: MPH s.n., t. 4, cz. 1, Warszawa 1962, s. 3-47 [dalej: VA I/A]; por. J. Hoffmann, Vita Adalberti. Früheste Textüberlieferungen der Lebensgeschichte Adalberts von Prag, Essen 2005 (lekcje rękopisu z Akwizgranu: s. 33-50; wyd. tekstu: s. 126-159); The Life of Saint Adalbert Bishop of Prague and Martyr, wyd. i tłum. C. Gaspar, w: Vitae sanctorum aetatis conversionis Europae Centralis (saec. X-XI) / Saints of the Christianization Age of Central Europe (Tenth-Eleventh Centuries), red. G. Klaniczay, Budapest-New York 2013, s. 77-182 [dalej: C. Gaşpar, VA]. O tej ostatniej edycji zob. niedawno M. Sosnowski, Hagiografia doby chrystianizacji w nowej odstonie, Kwart. Hist., 122, 2015, z. 4, s. 877-901, tu s. 884 n.; por. też S. Wieczorek, „Bona stultitia”. O znaczeniu paradoksów retorycznych w najstarszym żywocie św. Wojciecha, Kwart. Hist., 122, 2015, z. 3, s. 417-455 (tu jednak nazbyt uproszczona wskazówka o „poleganiu” przez C. Gaşpara na tekście ustalonym przez J. Karwasińską, s. 417, przyp. 1).

${ }^{6}$ H. Mayo, Descriptive Inventories, s. 193.

7 Na k. 222v, 234v, 270v.

${ }^{8}$ Tym określeniem posłużyła się H. Mayo, Descriptive Inventories, s. 193. Próbkę pisma ostatnich składek kodeksu (k. 211r, 222v, 226r, 231r, 261r) udostępnia Kurzinventar der illuminierten (zob. wyżej w przyp. 2).

9 Por. A. Derolez, The Palaeography of Gothic Manuscript Books from the Twelfth to the Early Sixteenth Century, Cambridge-New York 2003.

${ }_{10}$ Podana niżej identyfikacja poszczególnych utworów polega głównie na wskazówkach H. Mayo, Descriptive Inventories, s. 195-198; por. też F. Lackner, Datierte Handschriften, cz. 1, s. 47. Piszący te słowa mógł sobie pozwolić jedynie na ich wyrywkową weryfikację.

${ }^{11}$ Układ kalendarzowy można by dostrzec co najwyżej w niewielkiej części zbioru: poz. [6]-[10]. 
zajmuje [1] Żywot św. Wolfganga Otloha od św. Emmerama (BHL ${ }^{12}$ 8990), uzupełniony o teksty oficjum o św. Wolfgangu (większość k. 222r). Na końcu, tj. w ostatnich dwóch wierszach prawej kolumny k. 222r, skryba dopisał czerwienią cenną wskazówkę: „Scriptum in Grein per Erhardum de Weytra anno Domini 1430"13. Następną stronicę rozpoczyna [2] Żywot św. Udalryka z Augsburga (k. 222v-230v), który okazuje się kompilacją opartą po części na dziele Bernona z Reichenau z dodaniem zbioru cudów świętego ${ }^{14}$. Przedostatnią historię, w której mowa o ocaleniu przez św. św. Udalryka i Konrada z Konstancji trzech zagrożonych dusz, pisarz kodeksu opatrzył komentarzem dokumentującym jego erudycję i zmysł krytyczny, a zarazem potwierdzającym geografię jego życiowego itinerarium: „Nota. Tale legitur in legenda de Pawmgartenperg de duabus animabus. Utrum idem uel aliud ab illo sit, diligenter vide" (k. 230v) ${ }^{15}$. Na dalszych kartach rękopisu znalazły się kolejno: [3] Żywot św. Maksymiliana (BHL $5812 ?^{16}$ ) - k. 231r-232v; [4] Pasja św. św. Teodory i Didymusa (BHL 8073) - k. 232v-234v; [5] Pasja św. Albana i towarzyszy (BHL 8111 ${ }^{17}$ ) - k. 234v-235v; [6] Żywot św. Wojciecha; [7] Pasja św. Walensa (BHL 8456) - k. 244v-245r; [8] Pasja św. Dezyderiusza z Langres pióra Warnahariusa (BHL 2145) k. 245r-246v; [9] Żywot św. Idziego (BHL 93, bez prologu) - k. 246v-250r; [10] Pasja (BHL 3081? ${ }^{18}$ ) oraz Translacja św. Fortunaty (BHL 3083) - k. 250r-253v; [11] Pasja św. Teodozji (BHL 8090) k. $253 \mathrm{v}-257 \mathrm{v}$ (tego utworu skryba nie przepisał w całości, zapewne z myślą o jego dokończeniu pozostawił pustą większą część k. 257v oraz całą k. 258, tj. resztę bieżącej składki), [12] teksty o św. Dionizym, biskupie Paryża: krótki wierszowany wstęp do żywota (inc. Alma Dyonisii hic scribitur vita beati) - k. 259r, Laudatio (BHL 2187) - k. 259r-261r oraz pasja zwana Post beatam et gloriosam (BHL $2178^{19}$ ) - k. 261r-263v; [13] Pasja św. Gereona i towarzyszy (BHL 3446) - k. 263v-265v; [14] Pasja św. Bonifacego (BHL 1413) - k. 265v-267v; [15] Pasja św. Zygmunta (BHL 7717) - k. 267v-268v; [16] Pasja św. Symforozy i jej synów (BHL 7971) - k. 269r-269v; [17] teksty o św. Katarzynie Aleksandryjskiej: Notabile, inc. In monte Synai corpus... - k. 269v-270r, De nomine, inc. Katherina dicitur a katha... (oparty na Zlotej legendzie) - k. 270r oraz pasja (BHL 1661m) - k. 270r-276r.

Wedle zgodnej opinii uczonych wszystkie wymienione teksty spisała jedna ręka, należąca - jak wynika z przytoczonego kolofonu - do „Erharda z Weitra”. Nie jest to imię skądinąd nieznane. Kłopoty z identyfikacją tej postaci wynikają raczej z embarras de richesse.

Jeśli wziąć pod uwagę przytoczone wskazówki chronologiczne i geograficzne (wzmianki o Grein an der Donau ${ }^{20}$ i pobliskim opactwie Cystersów w Baumgartenberg), najbardziej prawdopodobnym

12 Bibliotheca hagiographica latina antiquae et mediae aetatis, t. 1-2, wyd. Socii Bollandiani, Bruxellis 1898-1901, Novum Supplementum, wyd. H. Fros, Bruxelles 1986 [dalej, także w tekście głównym: BHL].

${ }^{13}$ Fot. kolofonu zob.: F. Lackner, Datierte Handschriften, cz. 2, s. 58, tabl. 63; Kurzinventar der illuminierten, <http://www. univie.ac.at/paecht-archiv-wien/ki/hzbg/hzbg hss webbilder/hzbg-cod 057/hzbg 057 222r.jpg> [dostęp: 28.12.2015].

${ }^{14}$ Szczegółowa charakterystyka redakcji zawartej w rękopisie herzogenburskim przekracza zakres niniejszych rozważań. Początek utworu - jak to zauważyła już H. Mayo - odpowiada redakcji BHL 8362 (bez prologu), zakończenie natomiast - BHL 8363. Na dolnych marginesach k. 223v-224r skryba, może czerpiąc z innej podstawy?, dodał ex post jakby uzupełnienie oparte na opuszczonym wcześniej (w większości) fragmencie BHL 8362 (cap. 7). Kodeks z Herzogenburga nie figuruje w wykazie rękopisów żywota pióra Bernona, jaki sporządził (wykorzystując dawniejsze studia W. Wolfa) D. Blume, Bern von Reichenau (1008-1048): Abt, Gelehrter, Biograph. Ein Lebensbild mit Werkverzeichnis sowie Edition und Übersetzung von Berns 'Vita S. Uodalrici', Vorträge und Forschungen. Sonderband, t. 52, Ostfildern 2008, s. 171-182.

15 Por. G. Winner, Katalog, s. 72 (początkowe słowa, z błędami).

16 Tak identyfikują utwór: H. Mayo, Descriptive Inventories, s. 196; F. Lackner, Datierte Handschriften, cz. 1, s. 47; W. Stelzer, 'Vita Maximiliani', w: Die deutsche Literatur des Mittelalters. Verfasserlexikon, t. 10, wyd. 2, Berlin-New York 1999, kol. 445; por. Katalog der lateinischen Handschriften der Bayerischen Staatsbibliothek München. Die Handschriften aus Augsburger Bibliotheken, t. 1: Stadtbibliothek Clm 3501-3661, oprac. E. Rauner, wstęp B. Gullath, Wiesbaden 2007 , s. 467. Wątpliwości wzbudza fakt, że bollandyści nie podają, jak brzmi desinit redakcji BHL 5812.

17 Tekst znany jest także jako Pasja św. Teonestusa i towarzyszy.

18 Taką identyfikację podają: H. Mayo, Descriptive Inventories, s. 197; F. Lackner, Datierte Handschriften, cz. 1, s. 47. W rękopisie z Herzogenburga utwór nie ma jednak właściwego BHL 3081 prologu. Być może, piszący te słowa nie zdołał tego sprawdzić, w grę wchodziłaby inna wersja utworu (BHL 3082?).

19 F. Lackner, Datierte Handschriften, cz. 1, s. 47, opatrzył tę identyfikację znakiem zapytania, nie thumacząc jednak swoich wątpliwości.

${ }^{20}$ Taka identyfikacja wskazanego w kolofonie „Grein”, zgodnie przyjmowana w literaturze przedmiotu, pozostaje poza dyskusją. 
kandydatem do roli skryby kodeksu z Herzogenburga wydaje się Erhart zwany Scriptor lub Scriptoris z Weitra, świecki duchowny mający święcenia kapłańskie, który w marcu 1426 r. zabiegał w Stolicy Apostolskiej o probostwo w Amstetten (niedaleko Grein an der Donau) ${ }^{21}$, a następnie, w czerwcu tego roku - o godność plebana w Sankt Leonhard am Forst (dalej od Grein, ale za to bliżej Herzogenburga)22. To on zapewne spisał także - przynajmniej w części - przechowywany w bibliotece opactwa Benedyktynów w Seitenstetten kodeks o sygn. 235. Księga mieści zbiór kazań oraz traktat franciszkanina Mikołaja $\mathrm{z}$ Liry Responsio ad quendam Iudaeum ex verbis evangelii secundum Mathaeum contra Christum nequiter arguentem. Kolofon wpisany na końcu tego tekstu informuje o jego ukończeniu w tymże roku 1426 ,per manus Erhardi de Weytra"23. Niewykluczone, że wszystkie przywołane wzmianki odnoszą się zarazem do Erharta, któremu kilkanaście lat wcześniej (28 II 1411) rodzice - Jan Gnöt mieszczanin z Weitra i jego żona Katarzyna - zapisali jako dziedzictwo majątek o wartości 75 funtów srebra, mając przy tym wzgląd - jak to wprost zaznaczyli - na jego „godność kapłańską” („,zw Füdrung priesterleicher wirdichait”) ${ }^{24}$.

Erhartem z Weitra zwał się również działający współcześnie przeor wiedeńskiego konwentu augustianów (eremitów). Pogląd o piastowaniu przezeń tej godności już w 1425 r. wydaje się jedynie skutkiem historiograficznego nieporozumienia ${ }^{25}$. Swoją funkcję pełnił on natomiast dowodnie u schyłku lat 40. i w następnej dekadzie XV w. ${ }^{26}$ Nie wiadomo, czy wiedeńczyka wolno identyfikować ze wspomnia-

${ }^{21}$ Repertorium Germanicum. Verzeichnis der in den päpstlichen Registern und Kameralakten vorkommenden Personen, Kirchen und Orte des Deutschen Reiches, seiner Diözesen und Territorien vom Beginn des Schismas bis zur Reformation, t. 4: Martin V (1417-1431), cz. 1-3, oprac. K.A. Fink, Berlin 1943-1958 (reprint: Hildesheim 1991-2000), tu cz. 1, kol. 661; por. tamże, cz. 2, kol. 2261. Zagadkę (zrodzoną najwyraźniej z niezidentyfikowanego dotąd błędu) stanowi pochodząca z 3 II 1426 suplika wzmiankująca zmarłego Erharda, proboszcza z Amstetten: tamże, cz. 1, kol. 436; Repertorium Germanicum, t. 4, Personenregister, oprac. S. Weiss, Tübingen 1979, s. 83.

22 Repertorium Germanicum, t. 4, cz. 1, kol. 661. Starania te spełzły na niczym, parafię w St. Leonhard am Forst objął Thomas Angelpeck; zob. np. tamże, cz. 3, kol. 3553 nn., 3810 n.

${ }^{23}$ Inventar der mittelalterlichen Handschriften des Benediktinerstiftes Seitenstetten, oprac. Ch. Glaßner, Wien 2005, s. 124, <www.ksbm.oeaw.ac.at/seit/inv/seitenstetten_inventar.pdf> [dostęp: 30.01.2016]; H. Cerny, Beiträge zur Geschichte der Wissenschaftspflege des Stiftes Seitenstetten im Mittelalter, „Studien und Mitteilungen zur Geschichte des Benediktinerordens und seiner Zweige", 78, 1967, s. 85. Do kodeksu z Seitenstetten piszący te słowa nie dotarł, tożsamość obu Erhartów pozostaje więc jedynie domysłem.

${ }^{24}$ Weitra, Stadtarchiv Urkunden (1321-1795), 141102 28, <http://monasterium.net/mom/AT-StaAWei/Urkunden/1411_02_28/ charter> [dostęp: 30.01.2016]; W. Katzenschlager, Archivbericht, Weitra 2010, s. 37, [cz.] B, nr 53, <http://www.weitra. gv.at/fileadmin/Ankuendigungen/Ankuendigungen 2012/Inventar Stadtarchiv.pdf $>$ [dostęp: 3.02.2016].

${ }_{25}$ Pod rokiem 1425 na liście przeorów konwentu wiedeńskiego umieścił go A. Kunzelmann, Geschichte der deutschen Augustiner-Eremiten, cz. 3: Die bayerische Provinz bis zum Ende des Mittelalters, Würzburg 1972, s. 310. W tym punkcie uczony powtórzył jednak tylko informację zaczerpniętą z analogicznego wykazu autorstwa F. Rennhofera, Die Augustiner-Eremiten in Wien. Ein Beitrag zur Kulturgeschichte Wiens, Würzburg 1956, s. 266. Ten z kolei nie wskazał jej źródła. Należy się domyślać, że za takowe uznał dokument („Revers”) przeora Erharda z 1425 r. dotyczący fundacji „des Hubmeister Jörg des Drechslers” (sic!), a wzmiankujący ołtarz NMP „unter dem Lettner”, o którym to dokumencie pisał (tamże, s. 77) w ślad za C. Wolfsgruberem (cytując najpewniej pracę: tenże, Die Hofkirche zu St. Augustin in Wien, Augsburg 1888). Studium tego ostatniego autora nie było niestety piszącemu te słowa dostępne. Wskazane okoliczności każą jednak podejrzewać, że „przeor Erhard” z 1425 r. zrodził się w istocie z pomyłki, jaką popełnił ongiś K. Lind, Über die drei mittelalterlichen Kirchen der Minoriten, Augustiner und Carmeliten in der Stadt Wien, „Berichte und Mittheilungen des Alterthums-Vereines zu Wien”, 5, 1861, s. 127-176, tu s. 163. To on doniósł o dokumencie z „29 VI 1425 r.”, w którym przeor Erhart z Weitra w zamian za fundację, jaką uczynił skarbnik Jörg der Dechser, zobowiązał się do codziennej mszy „auf dem Frauenaltar unter dem Lettner". Te i inne przytoczone przez badacza szczegóły nie pozwalają przecież wątpić, że miał w rzeczywistości na myśli zachowany do dziś, tej właśnie treści akt z 25 I 1455, Wiener Stadt- und Landesarchiv, Hauptarchiv-Urkunden (1177-1526), 3608, <http://monasterium.net/mom/AT-WStLA/HAUrk/3608/charter> [dostęp: 1.02.2016]; Regesten aus dem Archive der Stadt Wien, w: Quellen zur Geschichte der Stadt Wien [dalej: QGSW], seria II, t. 2, oprac. K. Uhlirz, Wien 1900, nr 3608, s. 369 n. Jego datację K. Lind musiał najwyraźniej mylnie odczytać (błąd w dacie dziennej wynikł z pomieszania dwóch świąt św. Pawła, w dokumencie wyraźnie wskazano święto styczniowe: „an sand Pauls tag seiner Bekerung”). Błędną informację K. Linda uwzględnił potem (we własnym wykazie przeorów konwentu wiedeńskiego) A. Mayer, Das kirchliche Leben und die christliche Caritas (Wohlthätigkeitsanstalten), w: Geschichte der Stadt Wien, t. II/2, red. A. Starzer, Wien 1905, s. 867-960, tu s. 882, przyp. 2.

${ }^{26}$ Niederösterreichisches Landesarchiv, Urkundensammlung des Ständisches Archivs, 2682 (8 X 1449), <http://www.noela. findbuch.net/perma_arid-3695-bekurz-5374412055726b-vnum-3564.html> [dostęp: 14.04.2016]; A. Starzer, Regesten aus 
nym kapłanem (wyobrażając sobie, że ten porzuciwszy karierę świeckiego duchownego, przystał do augustianów), czy też rozpoznać w nim drugiego - ze względów chronologicznych nieco mniej prawdopodobnego - kandydata na skrybę omawianego kodeksu.

W tamtych czasach w Wiedniu działał wreszcie inny jeszcze imiennik wymienionych: Erhart Vogt z Weitra. Uczony, komentator Arystotelesa, studiował, a następnie wykładał na Uniwersytecie Wiedeńskim (immatrykulowany w 1439 r., magister artium w 1446 r., później bakałarz prawa, tamże) ${ }^{27}$. Teoretycznie także on mógł sporządzić hagiograficzną kolekcję z rękopisu herzogenburskiego. Taka ewentualność wzbudza jednak większe wątpliwości: gdyby tak było, innymi słowy gdyby już w $1430 \mathrm{r}$. był osobą dojrzałą, immatrykulacja późniejsza aż o 9 lat pozostawałaby trudną do rozwikłania zagadką.

Nie są znane związki którejkolwiek z wymienionych postaci z klasztorami Kanoników Regularnych w Herzogenburgu ani (sens tej uwagi stanie się jasny za chwilę) Klosterneuburgu. Wiadomo jedynie, że przeor Erhart i wiedeńscy augustianie utrzymywali kontakty z miejscowym konwentem kanoników pw. św. Doroty ${ }^{28}$. Nie od rzeczy będzie natomiast przypomnieć, że prawo patronatu do kościoła parafialnego w Grein należało w pierwszej połowie XV w. do innego jeszcze domu kanoników regularnych, położonego w niedalekim Waldhausen ${ }^{29}$.

Bez jasnej odpowiedzi pozostać musi pytanie o powody, dla których Erhart z Weitra sporządził swoje małe legendarium. Niewykluczone oczywiście, że traktował je jako narzędzie własnego duchowego doskonalenia ${ }^{30}$. Kryteria, jakimi kierował się w doborze tekstów, można co najwyżej próbować odgadnąć. Miejsce jego pobytu i pracy - Grein an der Donau - pozwalałoby wyjaśnić zainteresowanie kultem św. Idziego (takie wezwanie nosił tutejszy kościół parafialny) i św. Katarzyny (w Grein znajdowała się poświęcona jej kaplica) ${ }^{31}$. Z kolei cześć dla św. Wolfganga dałoby się chyba tłumaczyć jego pochodzeniem, tj. kojarzyć z ufundowanym w początkach XV w., noszącym wezwanie tego orędownika, pielgrzymkowym kościołem w Pfaffenschlag (obecnie St. Wolfgang), położonym ledwie kilka

dem k. k. Archiv für Niederösterreich, w: QGSW, seria I, t. 5, oprac. A. Starzer, Wien 1906, nr 4919, s. 40 n. (31 III 1450 ); Regesten aus dem Archive der Stadt Wien, t. 2, nr 3608, s. 369 n. (25 I 1455); H. Pfeiffer, Regesten aus dem Archive des 1786 aufgehobenen Chorherrenstiftes St. Dorothea in Wien, w: QGSW, seria I, t. 3, oprac. A. Mayer, Wien 1897, nr 2408, s. 32 (21 II 1455); Wiener Ratsurteile des Spätmittelalters, wyd. H. Demelius, Wien-Köln-Graz 1980, nr 99, s. 240-243 (4 VIII 1459, Erhart nie jest tu wprost tytułowany przeorem: „bruder Erhart von Weitra, anstat des prior vnd conuents”); K. Lind, Über die drei mittelalterlichen Kirchen, s. 163; A. Mayer, Das kirchliche Leben, s. 882, przyp. 2; F. Rennhofer, Die Augustiner-Eremiten, s. 266; A. Kunzelmann, Geschichte, s. 310 n. i przyp. 1188. Zdjęcia niektórych przywołanych dokumentów udostępnia portal: monasterium.net.

${ }^{27}$ Die Matrikel der Universität Wien, t. 1, Quellen zur Geschichte der Universität Wien, Graz-Köln 1956, s. 213; Wiener Artistenregister 1416-1555, oprac. T. Maisel, I. Matschinegg, A. Bracher, Wien 2007, <https://phaidra.univie.ac.at/view/o:217> [dostęp: 21.04.2016], nr 8498, 9013, 9155, 9535, 9862, 10008, 10272, 10632, 10700, 10981; J. Aschbach, Geschichte der Wiener Universität im ersten Jahrhunderte ihres Bestehens, Wien 1865, s. 601; Ch.H. Lohr, Medieval Latin Aristotle Commentaries. Supplementary Authors, „Traditio”, 30, 1974, s. 133 n.; M. Markowski, Abhandlungen zur Logik an der Universität Wien in den Jahren 1365-1500, „Studia Mediewistyczne”, 22, 1983, nr 1, s. 72; por. jednak tenże, Wiedeńskie komentarze do dziet Arystotelesa w rękopisie 749 biblioteki benedyktynów w Admont, „Studia Antyczne i Mediewistyczne”, 36, 2003, s. 174. „Mistrz” Erhart z Weitra występuje też w dwóch dokumentach wystawionych w Wiedniu w 1458 r.: Regesten aus dem Archive der Stadt Wien, t. 3, nr 3787 (22 VI), s. 9 n., nr 3802 (26 VII), s. 13 (oryginały można oglądać na portalu: monasterium.net). Z pierwszego z nich wynika, że należał do grona octogenarii (die Achter) wiedeńskiej kolegiaty św. Szczepana.

${ }^{28}$ H. Pfeiffer, Regesten, nr 2408, s. 32; M. Fischer, Historische Darstellung des Stiftes der regulirten lateranensischen Chorherren St. Dorothea zu Wien bis zu dessen Vereinigung mit dem Stifte Klosterneuburg, w: Topographie des Erzherzogthums Oesterreich, t. 15, Wien 1836, s. 53.

${ }^{29}$ H.Fr.X. Müller, Die kirchenrechtlichen Verhältnisse des Augustiner-Chorherrenstiftes Waldhausen im Spätmittelalter. Seine Anfänge und sein Pfarrnetz, „Jahrbuch des Oberösterreichischen Musealvereines”, 113, 1968, nr 1, s. 88-90, $104,108$.

${ }^{30} \mathrm{Na}$ marginesach zdarza się słowo „nota” wyróżniające miejsca uznane za godne uwagi (np. ustęp o przyczynach porzucenia przez św. Wojciecha biskupstwa, na k. 238v), na marginesie k. 256v narysowano nawet dłoń wskazującą palcem (najwyraźniej jako ważny) biblijny cytat w następującym fragmencie Pasji św. Teodozji: „Semper domestica cura contraria est anime saluti quia sicut scriptum est: Inimici hominis domestici eius” (Mi 7,6; Mt 10,36).

${ }^{31}$ W 1361 r. dwunastu biskupów wystawiło w Awinionie przywilej odpustowy dla „kościoła parafialnego świętego Idziego i kaplicy świętej Katarzyny w Grein”: Urkunden-Buch des Landes ob der Enns, t. 8, Wien 1883, nr 27, s. 24 n. 
kilometrów na południe od Weitra ${ }^{32}$. Co do reszty prac $-\mathrm{z}$ Żywotem św. Wojciecha włącznie - motywacje skryby trudno wyświetlić. W jego zbiorze zdecydowanie przeważają dzieła poświęcone męczennikom (wyjątkami są teksty o Wolfgangu [1], Idzim [9] i Udalryku [2]). Czyżby w takiej predylekcji wolno było dostrzec swego rodzaju signum temporis? W latach 20. XV w. północna Austria niejednokrotnie padała ofiarą najazdów husyckich. Dotknęły one także okolice Grein: w 1428 r. - a więc na krótko przed powstaniem zbioru Erharta - zniszczone zostały m.in. dwa wspomniane wyżej, pobliskie klasztory: kanonicki w Waldhausen i cysterski w Baumgartenberg ${ }^{33}$. Miejscowemu duchowieństwu perspektywa śmierci męczeńskiej nie musiała się więc wydawać czymś odległym i nierzeczywistym...

Zawarte w przytoczonej wyżej nocie wskazówki na temat czasu i miejsca pracy Erharta, chociaż same w sobie nie budzą podejrzeń, w sposób niewątpliwy odnoszą się jednak wyłącznie do poprzedzających je tekstów o św. Wolfgangu. Powstaje pytanie, czy z równą precyzją określają miejsce i czas przepisania pozostałych prac (a więc także Vita s. Adalberti) ${ }^{34}$ Pewne drobne przesłanki mogą sugerować, że między zapisaniem pierwszej składki (do jej przedostatniej stronicy włącznie) a zapisaniem reszty skryba zrobił przerwę. Zwraca uwagę fakt, że papier pierwszego seksternionu ma inne znaki wodne (wzgórze o trzech wierzchołkach z prostym krzyżem łacińskim) niż papier pięciu pozostałych składek (waga) ${ }^{35}$. Co więcej, poczynając od k. 223 (jest to pierwsza karta drugiej składki) zmienia się nieco sposób liniowania stronic: delikatne wcześniej kreski wyznaczające granice kolumn pisma ustępują miejsca stosunkowo grubym liniom wykonywanym atramentem. Wreszcie sam fakt wpisania przypominającej kolofon noty z wizytówką skryby wskazuje swego rodzaju cezurę, każąc przypuszczać, że w tym miejscu Erhart dostrzegł - jak się miało okazać, tymczasowy jedynie - finał swojej pracy. Nie są to argumenty rozstrzygające. Ważnej wskazówki dostarczy na pewno - pozostająca na razie badawczym postulatem - analiza herzogenburskiej kopii Żywota św. Wolfganga. Jeśli okaże się, że jej pierwowzór pochodził z tego samego kodeksu, z którego Erhart przepisał inne utwory, hipotezę o (dłuższej) przerwie w pisaniu trzeba będzie pewnie odrzucić. Do czasu, gdy to nie nastąpi, rok 1430 należy jednak traktować raczej jako terminus a quo spisania herzogenburskiej kopii Żywota św. Wojciecha (i innych towarzyszących mu dzieł). Nie ma wcale pewności, czy Erhart z Weitra cały czas pracował w Grein an der Donau.

Spośród wszystkich wyliczonych wyżej tekstów hagiograficznych z kodeksu o sygn. 57 jak dotąd tylko jeden doczekał się próby identyfikacji swojego rękopiśmiennego pierwowzoru. Cécile Lanéry badająca tradycję rękopiśmienną Pasji św. św. Teodory i Didymusa (BHL 8073) doszła do wniosku, że jej kopia z kodeksu herzogenburskiego powstała na podstawie zachowanego do dziś, XII-wiecznego rękopisu z klasztoru Kanoników Regularnych w Klosterneuburgu o sygn. 707. Uczona zauważyła, że manuskrypt ten - mieszczący obszerną, bo liczącą 40 utworów, kolekcję hagiograficzną - zawiera także inne teksty występujące $\mathrm{w}$ rękopisie herzogenburskim ${ }^{36}$. W istocie znaleźć tu można (kolejność

32 Zob. G. Brucher, St. Wolfgang bei Weitra, w: Gotik, red. G. Brucher, Geschichte der bildenden Kunst in Österreich, t. 2, München-London-New York 2000, s. 292 n. (z podaniem starszej literatury).

${ }^{33}$ F.X. Pritz, Geschichte des aufgelassenen Stiftes der regulirten Chorherren des heil. Augustin zu Waldhausen im Lande ob der Enns, „Archiv für Kunde Österreichischer Geschichts-Quellen”, 9, 1853, s. 305-351, tu s. 341; tenże, Geschichte des aufgelassenen Cistercienser-Klosters Baumgartenberg im Lande ob der Enns. Aus Urkunden und anderen Quellen, „Archiv für Kunde Österreichischer Geschichts-Quellen”, 12, 1854, s. 1-62, tu s. 37 n.; F. Stöller, Österreich im Kriege gegen die Hussiten (1420-1436), „Jahrbuch für Landeskunde von Niederösterreich”, NF, 22, 1929, s. 1-87, tu s. 52.

${ }^{34}$ Cyt. wyżej opisy inwentarzowe nie roztrząsają tej kwestii; por. np. H. Mayo, Descriptive Inventories, s. 193, por. jednak tamże, s. 198 (,,about 1430”).

${ }^{35}$ Szczegółowe rozpoznanie filigranów kodeksu, które notabene wydają się występować w różniących się nieco między sobą wariantach, wymaga studiów przekraczających możliwości autora. W tym miejscu wystarczyć więc muszą najogólniejsze tylko wskazówki: „wzgórze z krzyżem” przypomina kształtem znaki skatalogowane przez G. Piccarda, Wasserzeichen Dreiberg, Die Wasserzeichenkartei Piccard im Hauptstaatsarchiv Stuttgart Findbuch, t. 16, cz. 1, Stuttgart 1996, cz. 2, s. 55-173; „waga” reprezentuje typ podobny do tych, które zestawił tenże, Wasserzeichen Waage, Die Wasserzeichenkartei Piccard im Hauptstaatsarchiv Stuttgart Findbuch, t. 5, Stuttgart 1978, cz. 1, s. 41-74.

36 C. Lanéry, La Passion de Théodora et Didyme. Édition des traductions latines BHL 8072 et 8073, „Analecta Bollandiana”, 122, 2004, s. 5-50, tu s. 14 n. 
odpowiada układowi rękopisu z Klosterneuburga, w nawiasach podano numery określające miejsce tych samych utworów w manuskrypcie z Herzogenburga): trzy wymienione wyżej teksty o św. Dionizym [12], Pasję św. Gereona i towarzyszy [13], Pasję i Translację św. Fortunaty [10], Żywot św. Wolfganga autorstwa Otloha [1], Pasję św. Teodozji [11], Żywot św. Wojciecha [6], Pasję św. św. Teodory i Didymusa [4], Pasję św. Walensa [7], Pasję św. Dezyderiusza [8], Pasję św. Bonifacego [14], Pasje św. Albana i towarzyszy [5], Pasję św. Symforozy i jej synów [16], Pasję św. Zygmunta [15] ${ }^{37}$. Trudno oprzeć się podejrzeniu, którego udokumentowanie wymagałoby jednak szerzej zakrojonych studiów porównawczych, że kodeks Klosterneuburg, Stiftsbibliothek 707 był nie jedynym wprawdzie, ale głównym źródłem, z którego Erhart z Weitra zaczerpnął teksty do swojej kolekcji.

Analiza herzogenburskiej kopii najstarszego Żywota św. Wojciecha [dalej: Hb] stanowić może (ma się rozumieć: jedynie cząstkową) przesłankę potwierdzającą taki domysł. Ujawnia liczne, a co ważniejsze wysoce znamienne zbieżności właśnie z dobrze znaną XII-wieczną kopią Żywota z kodeksu Klosterneuburg, Stiftsbibliothek 707, k. 107r-119v [w ślad za J. Karwasińską dalej: Kn ]. Pokrewieństwo obu rękopisów każe podejrzewać już sam - wykazujący niewielkie tylko odchylenia - podział utworu na rozdziały ${ }^{38}$, ale w sposób rozstrzygający przekonuje o nim porównawcza analiza poszczególnych fragmentów tekstu.

Należy na wstępie zauważyć, że tę ostatnią utrudniają w pewnym stopniu błędy, które wkradły się do aparatu krytycznego wydania J. Karwasińskiej. Jakże skądinąd zasłużona edytorka w niektórych przypadkach w sposób nieprecyzyjny lub zgoła fałszywy informuje o lekcjach $K n_{1}^{39}$. Miarodajna ocena stopnia wzajemnej zależności $H b$ i $K n$, wymagała więc autopsji rękopisu klosterneuburskiego ${ }^{40}$.

Wśród wielu charakterystycznych koincydencji dowodzących pokrewieństwa obu manuskryptów ${ }^{41}$ na wyróżnienie zasługują zwłaszcza te wspólne im lekcje, które nie mają żadnych analogii w innych kopiach Żywota. Tylko $\mathrm{Hb}$ i $K n_{1}$ opuszczają (w całości) ostatnie zdanie rozdziału $29^{42}$, tylko one wykazują takie odmianki jak np.: baptismatis w miejsce crismatis (cap. 3), audi miast accipe (cap. 15), faceret zamiast fierent (cap. 17), cursu, a nie gressu (cap. 19), agnouimus, agnouimus w miejsce agnoscimus (cap. 26), lucienses na określenie Luciców (cap. 27), brak słów carine et (cap. 28), sopifera, a nie soporifera (cap. 30) ${ }^{43}$.

Co więcej, niektóre lekcje właściwe wyłącznie $H b$ da się bez trudu wywieść z nieznacznie tylko różnych, a skądinąd również unikalnych sformułowań $K n_{l}$. Pojawiającą się jedynie u Erharta z Weitra lekcję: gregorius (cap. 14) można wyjaśnić jako rozwinięcie zastosowanego przez kopistę Kn nietypowego skrócenia gregs ${ }^{44}$. Występująca w $H b$ lekcja: ut quasi per se (cap. 29) tłumaczy się uwzględnieniem

${ }^{37}$ Por. H. Pfeiffer, B. Černík, Catalogus codicum manu scriptorum, qui in bibliotheca Canonicorum Regularium s. Augustini Claustroneoburgi asservantur, Klosterneunburg b.d.w. [rkps], t. 4, s. 964-974, <http://manuscripta.at/_scripts/php/ newWin4msDescription.php?ID=914> [dostęp: 20.01.2016]. O kodeksie Klosterneuburg, Stiftsbibliothek 707, zob. też ostatnio D.Ó. Riain, The „Magnum Legendarium Austriacum”. A New Investigation of One of Medieval Europe's Richest Hagiographical Collections, „Analecta Bollandiana”, 133, 2015, s. 87-165, zwł. s. 124-128.

${ }^{38}$ Wyjąwszy dwa początkowe (wyróżnione za pomocą wykonanych czerwonym i niebieskim atramentem inicjałów) $H b$ nie dzieli tekstu na akapity (sensu stricto), zaznacza jednak ich granice za pomocą znaku interpunkcyjnego w formie dwóch małych, ukośnych kreseczek: //. W ośmiu przypadkach odbiega od podziału właściwego Kn (który notabene dzieli tekst dużo czytelniej), scalając wyodrębnione tu ustępy. Raz tylko (k. 242rb, od słów: „Hoc autem non sic...”; VA I/A, cap. 23, s. 35) wyróżnia nowy ustęp tekstu tam, gdzie $K n_{l}$ go nie wskazuje.

39 Zob. niżej, Aneks 3.

${ }^{40}$ Piszący te słowa wykorzystał w tym celu mikrofilm odpowiednich partii manuskryptu uzyskany z Hill Museum \& Manuscript Library, Saint John's University, Collegeville, Minnesota.

${ }^{41}$ Skalę tych zbieżności - na tle różnic zachodzących między $H b$ a tekstem redakcji cesarskiej Vita prior w brzmieniu przyjętym przez J. Karwasińską - pozwala w pełni ocenić zestawienie zamieszczone w Aneksie 1.

42 Aneks 1, poz. 344.

${ }^{43}$ Aneks 1, poz. 27, 157, 174, 203, 298, 306, 312, 350; zob. ponadto poz. 4, 14, 18, 36, 37, 41, 52, 55, 65, 67, 91, 99, 110, $115,116,118,124,125,130,131,136,140,150,153,154,171,178(?), 181,185,191,193,205,215,216,235,258,283$, $295,302,319,323,336,360,362$. Jako znaczący wskazać trzeba przy tym fakt, że w niektórych podanych przypadkach (poz. 130, 157, 181) lekcja $K n_{1}$ obejmuje dopisek interlinearny lub marginalny, który w $H b$ wciągnięto do tekstu.

${ }_{44}$ Aneks 1, poz. 137. 
poprawki dodanej na marginesie $K n_{l}$, przy jednoczesnym pominięciu powtórzonego tu omyłkowo $u t^{45}$. Jeśli nagłówek Vita prior w $\mathrm{Hb}$ różni się od incipitu z $K n_{l}$, to jedną tylko literą: Erhart poprawił Adelberti na Adalberti ${ }^{46}$.

Bliskie związki filiacyjne obu rękopisów nie budzą więc wątpliwości. Pozostaje - na drodze analizy lekcji różnych - ocenić, czy $\mathrm{Hb}$ stanowi po prostu kopię $K n_{l}$, czy też oba manuskrypty miały wspólny, a zaginiony obecnie pierwowzór ${ }^{47}$, czy może Erhart z Weitra dysponował więcej niż jedną podstawą i dokonał kontaminacji. Jak wiadomo, klasztor w Klosterneuburgu po dziś dzień posiada inny jeszcze kodeks mieszczący odmienną od Kn $n_{1}$ kopię Vita prior ${ }^{48}$.

Większość tych lekcji $H b$, które odróżniają go od $K n_{l}$, okazuje się pozbawiona wszelkich w ogóle analogii w tradycji rękopiśmiennej $\dot{Z} y w_{\text {wota }}{ }^{49}$. Są to z pewnością błędy własne Erharta z Weitra, już to omyłki czy opustki wynikłe z nieuwagi lub zmęczenia ${ }^{50}$, już to zmiany wprowadzone świadomie. Te ostatnie rzadko kiedy oznaczają niewielką niechby ingerencję w treść utworu (największa bodaj innowacja polega na dodaniu niemieckiej nazwy Magdeburga: „,id est maidewurch”) ${ }^{51}$, częściej mają postać drobnych poprawek językowych ${ }^{52}$, by nie wspominać o wynikłych z predylekcji kopisty korektach ortograficznych ${ }^{53}$. Zdarza się oczywiście, że odróżnienie świadomej poprawki od pomyłki bywa trudne (jak np. w przypadku zmiany szyku wyrazów) ${ }^{54}$, ale wątpliwości tego rodzaju nie mają dla dyskusji nad filiacją rękopisów znaczenia.

$\mathrm{Na}$ baczniejszą uwagę zasługują miejsca, w których $H b$ wykazuje lekcję różną od $K n_{l}$, ale skądinąd znaną. Także te lekcje - jeśli przyjrzeć się im uważnie - nie pozwalają jednak podejrzewać istnienia innej niż $K n$, podstawy $H b$. Gros owych różnic (a z drugiej strony zbieżności) da się z powodzeniem wyjaśnić samodzielnymi poprawkami wprowadzonymi przez Erharta z Weitra tam, gdzie u kopisty z Klosterneuburga napotkał obcą sobie ortografię ${ }^{55}$ lub łatwy do naprawienia błąd ${ }^{56}$. Na skutek takich modyfikacji niejednokrotnie upodobnił swoją kopię Vita prior do innych, czasem także wczesnych rękopisów (na przekór $K n_{l}$ ). Powstałe w ten sposób drobne koincydencje (dotyczą pojedynczych słów) nie mogą stanowić oparcia dla hipotezy o zaginionym manuskrypcie lub kontaminacji ${ }^{57}$. Najcelniejszą bodaj poprawką Erharta wydaje się przywrócenie oryginalnej lekcji iudeus w opowieści o powodach opuszczenia przez św. Wojciecha Pragi (cap. 12). Kn ma w tym miejscu gramatycznie poprawne, ale

45 Aneks 1, poz. 196.

46 Aneks 1, poz. 1.

${ }^{47}$ Oczywiście, wobec faktu, że w kilku miejscach $H b$ wciąga do tekstu dopiski interlinearne lub marginalne kopisty $K n_{l}$, taka hipoteza już na pierwszy rzut oka nie wydaje się zbyt prawdopodobna.

${ }^{48}$ Klosterneuburg, Stiftsbibliothek 708, k. 170r-186v; VA I/A, wstęp wydawcy, s. XVI $\left(K n_{2}\right)$. O całym tym kodeksie zob. ostatnio D.Ó. Riain, The „Magnum Legendarium Austriacum”, zwł. s. 110 nn. (z datacją na ok. 1300 r.).

49 Nie zawsze można mieć pewność, czy lekcje $K n_{l}$ i $H b$ są różne, czy tożsame: Aneks 1, poz. 104, 111 (niejednoznaczne skrócenia). Raczej zgodność upatrywać należy w dwóch innych przypadkach: Aneks 1, poz. 268; Aneks 2, poz. 8.

${ }^{50}$ Zob. Aneks 1, poz. 7, 23, 32, 34, 127, 143 (największa opustka), 155, 164, 206, 273, 315, 318, 329, 331, 346. Pewną liczbę własnych błędów Erhart zdołał wychwycić i poprawić. Z tych interwencji (przeróbek, skreśleń) w zamieszczonym niżej Aneksie 1 uwzględniono tylko te uznane za bardziej interesujące (co nie znaczy: największe).

${ }^{51}$ Aneks 1, poz. 19, zob. też poz. 124, 222, 262, 277, 304.

${ }^{52}$ Zob. Aneks 1, poz. 53, 123, 145, 158, 167, 184, 186, 190, 195, 241, 255, 276, 316, 321, 364; zob. też przypadki omówione wyżej: Aneks 1, poz. 1, 196.

${ }_{53}$ Zob. niżej, przyp. 62, oraz Aneks 1, poz. 44, 210, 211, 245, 288, 309, 313, 314, 365, może też poz. 41, 80, 225.

${ }_{54}$ Zob. Aneks 1, poz. 6, 10, 20, 47, 79, 92, 96, 147, 177, 207, 223, 234, 261, 263, 264, 265, 289, 328, 353.

55 Aneks 1, poz. 2, 22, 95, 129, 133, 187, 194, 214, 227, 229, 308; Aneks 2, poz. 5-7, 17. Podobnie trzeba rozumieć zamianę domni na domini (Aneks 2, poz. 15) oraz archaicznego palaniorum na powszechne w XV w.: polonorum, tj. na formę znaną też z innych późnych rękopisów Żywota (Aneks 1, poz. 292). Poza nawias rozważań można natomiast wyłączyć skądinąd problematyczną, a na pewno nieistotną, ortograficzną odmiankę: Aneks 1, poz. 253 (jej ewentualne inne wystąpienia wymagałyby kwerendy).

${ }^{56}$ Aneks 2, poz. 2-4,10,11,13,14,18, 20-24. Jako rezultat poprawienia lekcji uznanej za błędną trzeba też rozumieć: Aneks 1, poz. 330; Aneks 2, poz. 1; zob. też przyp. następne.

57 To samo dotyczy czterech dalszych zmian wynikłych najpewniej z prób udoskonalenia podstawy: Aneks 1, poz. 226 (=Aneks 2, poz. 16), 337 (nieco bardziej intrygujący przypadek), 358; Aneks 2, poz. 12 (drobna, ale kongenialna poprawka). 
pozbawione sensu uidens ${ }^{58}$. Najwyraźniej dostrzegając ów semantyczny niedostatek, Erhart zapoznał się $\mathrm{z}$ dalszym ciagiem opowiadania, na tej podstawie zidentyfikował omyłkę i skutecznie ją wyeliminował. Trafną zamianę błędnego feruoris na oryginalne furoris (cap. 26) ułatwiła pewnie erudycja biblijna ${ }^{59}$.

Niewielka grupa analogii między $\mathrm{Hb}$ a innymi rękopisami (na przekór $K n_{1}$ ) wynikła wreszcie - rzecz na pozór paradoksalna - z omyłek samego Erharta. Są to przecież także zbieżności drobne, dotyczą pojedynczych słów (jeśli nie liter), względnie szyku wyrazów (w parze) ${ }^{60}$. Każdą z nich traktować należy jako dzieło przypadku. Na pewno nie uprawniają one do twierdzenia, że skryba $H b$ dysponował jakimkolwiek innym niż Kn $n_{1}$ egzemplarzem Vita prior.

Porównanie lekcji $\mathrm{Hb}$ z lekcjami pozostałych rękopisów nie pozostawia więc wątpliwości, że wpisując do swojego małego legendarium Żywot św. Wojciecha, Erhart z Weitra wykorzystał jako jedyną podstawę zachowany do dziś kodeks Klosterneuburg, Stiftsbibliothek 707 . W tej sytuacji stworzona przezeń kopia nie może oczywiście pomóc w studiach nad oryginalnym brzmieniem utworu. Stanowi jedynie stosunkowo późne świadectwo jego skądinąd długiej historii. Niestety, przy obecnym stanie badań nie da się odpowiedzieć na pytanie, w jakich okolicznościach Erhart dostał do rąk rękopis klosterneuburski ani też, w jaki sposób jego własny manuskrypt trafił następnie do Herzogenburga. Klucz do rozwikłania obu kwestii zdają się stanowić kontakty austriackich konwentów kanoników regularnych (czy poza Klosterneuburgiem i Herzogenburgiem jakąś rolę odegrał też klasztor w Waldhausen?), ale zważywszy na powikłane losy herzogenburskiego księgozbioru trudno w tym względzie o pewne wnioski ${ }^{61}$. Ponieważ kopia Vita prior z legendarium Erharta nie wykazuje podziału na lekcje (do czytań liturgicznych), nie ma dowodów na jej wykorzystywanie w praktykach kultowych, czy to w Herzogenburgu, czy gdziekolwiek indziej. Nie są też znane żadne ślady jej recepcji ani w średniowieczu, ani w czasach nowożytnych.

58 Aneks 2, poz. 9.

${ }_{59}$ Aneks 2, poz. 19; por. zwł. Iz 13,9: „,irae furorisque”, często powraca wyrażenie „ira furoris”, zob. np. 2 Krl 23,26; 2 Krn 28,13; 30,8; Hi 20,23.

${ }^{60}$ Aneks 1, poz. 148, 189, 348 oraz 63, 183, 290 (zmiana szyku wyrazów mogła też być zabiegiem świadomym). Najbardziej frapujący, ale również drobny i najwyraźniej przypadkowy casus to: Aneks 1, poz. 351. W trzech innych miejscach lekcja $H b$ odpowiada wprawdzie $K n$, ale powstała na skutek poprawienia czy przerobienia lekcji znanej z innych rękopisów: Aneks 1, poz. 17, 82, 243. Także te koincydencje nie wydają się znaczące.

${ }^{61}$ Zob. W. Payrich, Herzogenburg, s. 72 n. 


\section{Aneks 1}

\section{Wykaz lekcji odróżniających $H b$ od tekstu redakcji „A" Vita prior ustalonego przez Jadwigę Karwasińską ${ }^{62}$}

\begin{tabular}{ll} 
Ip. & \multicolumn{1}{c}{ VA I/A, strona, wiersz } \\
1 & $\begin{array}{l}\text { 3, 1-2: Incipit passio sancti Adalberti } \\
\text { martiris Christi }\end{array}$ \\
& \\
2 & 3, 5: Sclauoniam \\
3 & 3, 5: cognomine \\
4 & 3, 7: uero \\
5 & 3, 10: uir \\
6 & $4,1:$ Zlaunic nomine \\
7 & $4,2:$ misericordię \\
8 & $4,4:$ precepta \\
9 & $4,6:$ eadem \\
10 & $4,10:$ oratione
\end{tabular}

4, 15: procreauerant

12 5, 1: Woietech

13 5, 3: uerum

14

15

5, 7: decurrunt
$H b$, karta, strona, kolumna

caput 1

235vb: De vita sancti Adalberti episcopi et martyris

235vb: Bohemiam

235vb: nomine

235vb: deest

$235 \mathrm{vb}$ : vir quidam

235vb: nomine Zlauncius

236ra: iusticie

236ra: preceptum

236ra: eademque

236ra: oracionibus

caput 2

236ra: procreauerat

236ra: Woitech

236ra: uel

236rb: discurrunt

caput 3

236rb: imbuitur

236rb: Adelbertum

\section{Rękopisy o lekcji zgodnej lub podobnej do $\mathrm{Hb}$}

De uita sancti Adelberti episcopi et martyris $K n_{l}$, De vita et passione sancti Adalberti episcopi et martiris sequitur $\mathrm{Wr}$

$\mathrm{Pr}_{2} \mathrm{Pr}_{3} \mathrm{TrOs}$, boemiam $\mathrm{WbKn} n_{1} \mathrm{Ad}_{2} \mathrm{St}$

$\mathrm{Kn}{ }_{1} \mathrm{Cr}$

$K n_{1}$

$K n_{1} A d_{2}$

Zlauntius nomine $K n_{l}$, nomine

Slawnyk $W r$

lectio unica

$K n_{1}[107 r] K n_{2}$ omnes praeter LsLlRv ${ }_{2} \operatorname{ZPr}_{1} W r G n A q$

lectio unica

$\mathrm{Kn} n_{1}[107 v] \mathrm{OsCr}$

$H k Z w_{1} W d M l K n_{1} K n_{2} A d_{2}$ $\mathrm{WbKn}_{1} \mathrm{Ad}_{2} \mathrm{Pr}_{2} \mathrm{StOs}$

$K n_{1}$

omnes praeter $\mathrm{LsPr}_{3} \mathrm{TrAq}_{\mathrm{A}}$

$\mathrm{Kn} n_{1}[107 v] \mathrm{St}$

62 Pominięto następujące oboczności w słowach pospolitych: -ci-/-ti- (Hb preferuje „,c”); -ae-/-ę-/-e- (Hb nie stosuje dyftongu ani „e caudata”); con-/com-; inp-/imp-/īp- (Hb ma najczęściej imp-); -u-/-v-; uu-/vu-/w- (Hb ma np. wlt, wlgus); -gu-/-gw-; ads-/ass-/as-; exs-/ex-; f-/ff-; -id/-it w końcówce 3 os. lp. (Hb ma zawsze -it); his/hiis oraz hi/hii (Hb stosuje formy ze zdwojonym „i'); -mn-/-mpn- (Hb - odmiennie od $K n_{1}$ - preferuje drugą formę, więc np. sompnum); -c-/-k-; -cr-/-chr-; -t-/-th-; -i-/-y- (Hb ma m.in. ymbre, phylosophie, ymo, ale też np. martirium); cotid-/cottid-; capel-/cappel- (Hb podwaja ,p"); baptiz-l baptis- (Hb ma najczęściej formę z „s”); mihi/michi; nihil/nichil; uelud/uelut; apud/aput; quecunquelquecumque/quecūque; obtulit/optulit ( $\mathrm{Hb}$ ma dwakroć tę drugą formę, inaczej niż Kn $n_{1}$; nunquam/numquam/nūquam (Hb skraca); quicquid/quidquid/ quitquid ( $\mathrm{Hb}$ konsekwentnie stosuje ostatnią formę). Zignorowano też różnice wynikłe z faktu, że poza dwoma przypadkami (k. 237va = VA I/A, cap. 7, s. 12; k. 239vb = VA I/A, cap. 15, s. 22) Hb nie używa słowa domnus, które zastępuje skrótem dla dominus (tj. dns z kreską abrewiacji). Pominięto wreszcie rozbieżności sprowadzające się do stosowania wielkiej/ małej litery, łącznej/rozłącznej pisowni przyimków z innymi wyrazami (to samo dotyczy: seipsum/se ipsum, nondum/non dum, si quid/siquid), a ponadto - poza wyjątkami, które wydały się interesujące - informacje o poprawkach dokonanych przez kopistę, jego interpunkcji i skrótach (wyjąwszy wątpliwe, z zasady rozwiązywanych). Ostatnia kolumna zestawienia polega na informacjach pochodzących z wydania J. Karwasińskiej (pominięto wskazówki dotyczące dopisków z czasów nowożytnych i późniejszych). Lekcje $A q$ dodano na podstawie edycji J. Hoffmanna. Tam, gdzie lekcja $K n_{l}$ odbiega - co ustalono na podstawie posiadanego mikrofilmu - od informacji edytorki, syglę Kn , zaopatrzono w adnotację wskazującą odpowiednią kartę rękopisu. Znak zapytania dodany niekiedy do określenia lectio unica lub do trzech kropek oznacza podejrzenia, że brak informacji o innych wystąpieniach danej lekcji wynika tylko z zasad przyjętych w edycji J. Karwasińskiej. Zastosowano następujące skróty: abbrev. - abbreviatio, del. - deletum/a, corr. - correctum/a, suprascr. - suprascriptum/a, adscr. - adscriptum/a, eras. - erasum/a, l. - littera, marg. - margo. 
Ip.

VA I/A, strona, wiersz

\begin{tabular}{ll}
\hline 17 & 6, 3: recessit \\
18 & 6, 3: sacrę urbi \\
19 & $\begin{array}{l}\text { 6, 4: ciuitas, grece Parthenopolis } \\
\text { uocatur }\end{array}$
\end{tabular}

6, 6: autem

\section{6, 10: crismatis}

\section{7, 1: Adalbertum}

7, 2: spiritus semper

7, 2: cucurrit

7, 8: domicilia confugit

7, 17: semet ipsum

8, 12: uero

8,12 : quia

9, 5: faciliore

9, 6: seculi amara

49

\section{9, 10: Adalbertus}

9, 11: transuolarat

9, 15-16: adhuc magna pars animę

9, 17: Ei

10, 1: diuersus
$H b$, karta, strona, kolumna

236rb: corr. ex discessit

236rb: sacre tunc vrbi

236rb: ciuitas dicitur id est maidewurch grece parthenopolis

236rb: deest

236rb: semiruta pro peccatis

236rb: malefida

236rb: deest

236rb: Ipso in tempore

236va: Ohtricus

236va: sacrosancti

236va: baptismatis

236va: Adelbertum

236va: semper spiritus

236va: currunt

\section{caput 4}

236va: confugit domicilia

236va: sempiternum

236va: deest

236va: duitici

236va-b: spirituali

236vb: deest

\section{caput 5}

236vb: Concurrerunt

236vb: quid nam

236vb: cachinio

236vb: autem

236vb: qui

236vb: erat eius pater

237ra: faciliori

237ra: amara seculi

\section{caput 6}

237ra: Adelbertus

237ra: transuolauit

237ra: magna pars anime adhuc

237ra: heu

237ra: mutatus
Rękopisy o lekcji zgodnej lub podobnej do $\boldsymbol{H b}$

$c f$. discessit $L l R v_{2} A q$ (recessit reliqui)

$\mathrm{Kn}_{1}$, tunc del. $\mathrm{Ad}{ }_{2}$

lectio unica, ciuitas dicitur grece parthenopolis $K n_{l}$, ciuitas vulgariter meydeburg grece parthenopolis uocatur $W r$

lectio unica

$K n_{1} A d_{2}$

omnes praeter $\mathrm{Ls} \mathrm{ZfKn}{ }_{1} \mathrm{CrAq}$

lectio unica

$K n_{1} A d_{2}$

$\mathrm{WbKn}_{1} A d_{2}$

$L l R v_{2} B b S t O s W r A q$, sacro sancti in lineis divisis $\mathrm{HkZw}_{1} \mathrm{Zw}_{2} \mathrm{BgWdMlKn_{1 }}$ $\mathrm{Kn}_{2} \mathrm{Ad}_{2} \mathrm{Pr}_{3} \mathrm{TrCrGn}$

$K n_{1}$

$Z w_{1} K n_{1}$

$\mathrm{Kn}_{1} \mathrm{Ad}_{2} \mathrm{Pr}_{3}$

omnes praeter $\mathrm{LsPr}_{3} \mathrm{Cr}$

$\mathrm{Kn}_{1}[108 \mathrm{r}] \mathrm{Ad}_{2}$

lectio unica

$W b K n_{1} A d_{2} W r$

lectio unica

omnes praeter LsZfWrAq

$K n_{1}$

$K n_{1}[108 v]$, Concurrerunt corr. in Concurrunt $L s$, Concurrerunt omnes Gn

$\mathrm{Kn}_{1}$ [in lineis divisis, 108v]

$R v_{2} \operatorname{Pr}_{2} \operatorname{Pr}_{3} \operatorname{Tr} A q$

lectio unica

omnes praeter $\mathrm{LsLlRv} \mathrm{Zw}_{2} \mathrm{Aq}$

$K n_{1}[108 v]$

$\mathrm{Kn}_{1}[108 \mathrm{v}] \mathrm{Kn}_{2} \mathrm{Ad} \mathrm{d}_{2}$ omnes praeter LsLlWbAq

lectio unica

$H k Z w_{1} Z w_{2} B g W d M l K n_{1}$

$\mathrm{Kn}_{\mathrm{I}} \mathrm{Ad}_{2} \mathrm{Os}$

lectio unica

omnes praeter $L s L l R v_{2} Z f W b Z w_{2} W r G n$

$\mathrm{WbKn}_{1} A d_{2}$ 
Ip.

VA I/A, strona, wiersz
$H b$, karta, strona, kolumna

237ra: heu

237ra: deest

237rb: tamen ueniabile

237rb: esset erga pium dominum

237rb: nisi quod

237rb: nichil

237rb: dolebitque

237rb: moriuntur

237rb: deest

237rb: Adelbertus

\section{caput 7}

237rb: Adelbertus

237rb: administrat

237va: ecclesiam

237va: vos iactare

237va: eumque cum

237va: gentibus

237va: postera

237va: Albertus

237va: populus cum clero

caput 8

237va: sarracinico

237vb: acquiescens

237vb: magoncio

237vb: deest

237vb: deest

237vb: ore

237vb: ciuitatem sanctam

237vb: predictus

237vb: Wenzlaus

237vb: consummans

237vb: atque

\section{caput 9}

237vb: comoditatibus

238ra: deest

238ra: altis corr. ex altus

238ra: itur

\section{caput 10}

238ra: et in carcere
Rękopisy o lekcji zgodnej lub podobnej do $\mathrm{Hb}$

omnes praeter Ls

omnes praeter LlGn (ut eras. Ls, ut del. $\left.K n_{1}\right)$

$K n_{1}$

lectio unica

$\mathrm{WbKn}_{1} \mathrm{Ad}_{2}$

$K n_{1}$

$W b K n_{1} A d_{2}$

$W b W d K n_{1} \mathrm{Kn}_{2} A d_{2} \mathrm{Os} W r$

$L s L l R v_{2} W b K n_{1} O s A q$

$H k Z w_{1} Z w_{2} B g W d K n_{1}$

$H k Z w_{1} Z w_{2} B g W d K n_{1} K n_{2}$

$\mathrm{Kn}_{1} \mathrm{Ad}{ }_{2} \mathrm{Wr}$

$\mathrm{Kn},[109 v] \mathrm{Aq}$

$\mathrm{HkZw}_{1} \mathrm{Zw}_{2} \mathrm{BgWdMlKn_{2 }} \mathrm{Pr}_{2} \mathrm{Pr}_{3} \mathrm{TrStOsAq}$

$K n_{1} A d_{2}$

$K n_{1}$

$\mathrm{Kn}_{1} \mathrm{Ad}_{2} \mathrm{Os}$

$K n_{1}$

$\mathrm{ZfWbKn} \mathrm{Pr}_{2}$

$K n_{1}[109 v]$, saracinico $W b A d_{2}$

$\mathrm{Kn}_{1}[109 \mathrm{v}] \mathrm{Rv} \mathrm{R}_{1} \mathrm{Rv} \mathrm{ZfAd}_{2} \mathrm{BbPr}_{3} \mathrm{TrOs}$

magontio $K n_{1}$

LlWbKn,Aq

$K n_{1} A d_{2}$

$K n_{1} A d_{2}$

$R v_{1} R v_{2} K n_{1} A d_{2}$

$\mathrm{Kn}_{1} \mathrm{Ad}_{2} \mathrm{Pr}_{2}$

$Z w_{1} K n_{1}$

$L l R v_{1} R v_{2} H k Z w_{1} Z w_{2} W d M l K n_{1}[110 r]$

$\mathrm{Kn}{ }_{2}$

lectio unica

lectio unica? (commoditatibus $K n_{l}$ )

omnes praeter $L s L l R v_{1} R v_{2} G n A q$

altis $Z f W b H k Z w_{1} Z w_{2} B g B b W d M l K n_{1}$ $\mathrm{Kn}_{2} \mathrm{Ad}_{2} \mathrm{Pr}_{2} \mathrm{St} \mathrm{OsGn}$, altus $\mathrm{Pr}_{3} \mathrm{Tr}$

$W b K n_{1} A d_{2}$

Ll(suprascr.)ZfHkZw ${ }_{1} Z w_{2} B g W d M l K n_{1}$ (suprascr.) $\mathrm{Kn}_{2} \mathrm{BbPr}_{2} \mathrm{Pr}_{3} \mathrm{TrStOsGn}$ 
Ip.

VA I/A, strona, wiersz
$H b$, karta, strona, kolumna

238ra: aut

238ra: tempus seminis

238rb: genuum

238rb: flexionibus

238rb: exit

238rb: monastice

238rb: primam autem

238rb: aduena

238rb: dauiticis

238rb: opera

\section{caput 11}

238rb: hostia

238rb-va: clamorem mendici

238va: rugam

238va: complicuit

238va: eumque

238va: Willico

238va: prepositus

238va: inquirere

238va: forsan

\section{caput 12}

238va: desiert $u t$ videtur pro desierant

238va: sibi

238va: infirmis

238va: relapsi

238va: claues

238va: machinacionibus

238va: deest

238va: festinaūnt

238vb: perfide

238vb: compererunt

238vb: potestatis

238vb: ad hec

238vb: Admouit

238vb: Williconem

238vb: ceteris preerat

238vb: suorum esse participem fecit
Rękopisy o lekcji zgodnej lub podobnej do $\mathrm{Hb}$

\author{
$K n_{1} A d_{2}$ \\ $\mathrm{Kn}_{I} A d_{2}$ \\ omnes praeter $\mathrm{LsPr}_{3} \mathrm{Tr}$ \\ omnes praeter $L s L l R v_{1} R v_{2} W d B b A q$ \\ $\mathrm{Kn}_{1} \mathrm{St}$ \\ $\mathrm{Kn}{ }_{1}[110 v] A d_{2} G n$ \\ $K n_{1}$ \\ lectio unica \\ $L l R v_{l} R v_{2} Z f W b H k Z w_{l} K n_{l} B b T r A q$ \\ omnes praeter LsLlRv ${ }_{1} R v_{2} A q$ \\ $\mathrm{Zw}_{1} \mathrm{Kn}_{2} \operatorname{Pr}_{3} \operatorname{TrOsAq}$ \\ lectio unica \\ $W b K n_{1} A d_{2}$ \\ $L l R v_{1} R v_{2} W b K n_{I} A q$ \\ $K n_{1}[111 r]$ \\ $\mathrm{WbKn}_{1} A d_{2}$ \\ omnes praeter $L s L l R v_{1} R v_{2} A q$ \\ omnes praeter LsLlRv $v_{1} R v_{2} Z f G n A q$ \\ omnes praeter LsLlRv $v_{1} v_{2} Z f G n A q$
}

desierant $W b H k Z w_{1} B g W d M l K n_{l} K n_{2}$ $\mathrm{Ad}_{2} \mathrm{Pr}_{2} \mathrm{Pr}_{3} \mathrm{Tr} \mathrm{StOS}$

$\mathrm{WbKn}_{1} \mathrm{Ad}_{2}$

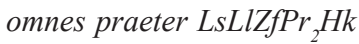

omnes praeter LsLlRv $v_{1} R v_{2} Z f G n A q$

$\mathrm{WbKn}_{1} \mathrm{Ad}_{2} \mathrm{Pr}_{3} \mathrm{Tr}$

$\mathrm{Kn}_{I} A d_{2}$

$K n_{1}$

festinauerunt $\mathrm{WbKn}_{I} \mathrm{Ad}_{2} \mathrm{Pr}_{3} \mathrm{Tr}$

$\mathrm{Kn}_{t} A d_{2}$

Ll(suprascr.)Rv $R v_{2} \mathrm{WbZw}_{1} \mathrm{MlKn}_{2} A d_{2}$ $\mathrm{Pr}_{2} A q$, conpererunt $Z w_{2} W d K n_{1}$

$H k K n_{l} A d_{2}$

$K n_{1}$

$K n_{1}$

$R v_{1} R v_{2} Z f W b H k Z w_{1} B g W d M l K n_{1}$ (adscr. in marg.) $\mathrm{Kn}_{2} \mathrm{Ad}_{2} \mathrm{BbSt}{ }^{63} \mathrm{Aq}$

$K n_{1}$

$K n_{1}[111 v] A d_{2} ?^{64}$

${ }^{63}$ Jako lekcję tych rękopisów J. Karwasińska podaje: Williconen, co wydaje się błędem drukarskim.

${ }^{64} \mathrm{Z}$ wydania J. Karwasińskiej, VA I/A, s. 18 i przyp. s-t, wynikałoby, że lekcja rękopisów $K n_{1}$ i $A d_{2}$, brzmi: „suorum esse participem" (bez fecit). W przypadku $K n_{l}$ jest to wskazówka błędna, rodzi się podejrzenie, że to samo dotyczy $A d_{2}$. 
lp. VA I/A, strona, wiersz

120 18, 17: mitissimus

121 19, 1: nos corpus

122 19, 7: foret acturus

123 19, 10: iusto

124 19, 18: dilecto

125 19, 20: erat

126 19, 21: euacuat

127 20, 2: augusta

128 20, 2: Theuphanu

129 20, 6: Hierosolimam

130 20, 7: posset, pro

131 20, 8: eadem

132 20, 9: nil

133 20, 12: Hierosolimis

134 20, 12: uisere

135 20, 12: Casinum

136 20, 13: construere

137 20, 15: Gregorii

138 21, 1: autem

139 21, 2: ceptum agere uellet

140 21, 2: illius

141 21, 3: inlustres

142 21, 3: arte

143 21, 6: sed cotidie loca noua mutare minus laudabile est

144 21, 7: est

145 21, 15: et labore

146 21, 15: parta

147 21, 17: omnes

148 22, 1: ira

149 22, 3: domus

150 22, 5: acto

151 22, 6: ętherio

152 22, 10: prouolutis
$H b$, karta, strona, kolumna

238vb: sanctissimus

238vb: nos sumus corpus

caput 13

239ra: agendum foret

239ra: iusticia

239ra: dileccione domini

239ra: deest

239ra: euacuauit

\section{caput 14}

239ra: deest

239ra: Theophana

239rb: iherosolimam

239rb: posset contradidit et pro

239rb: idem

239rb: nichil

239rb: ierosolimis

239rb: inuisere

239rb: cassinum

239rb: constituere

239rb: gregorius

239rb: deest

239rb: agere uellet ceptum

239rb: deest

239rb: illustres

239rb: arce

239va: deest

239va: deest

\section{caput 15}

239va: et a labore

239va: parata

239va: deest

239va: ita

239va: domos

239va: peracto

239va: ethereo

239vb: prouolutus
Rękopisy o lekcji zgodnej lub podobnej do $\mathrm{Hb}$

$$
\begin{aligned}
& K n_{1} A d_{2} \\
& W b K n_{1}
\end{aligned}
$$

$W b K n_{I} A d_{2}$

lectio unica

lectio unica, dilectione $\mathrm{Kn}{ }_{l}$

$K n_{1}$

omnes praeter $L s L l R v_{1} R v_{2} A q$

lectio unica (aliis mutatis augusta deest etiam Gn)

$\mathrm{Kn}_{1} A d_{2}$

$L l R v_{2} \mathrm{Kn}_{2} \mathrm{BbAq}$

$K n_{1}$ (et suprascr.)

$K n_{1}$

omnes praeter LsLlRv $v_{2} \mathrm{~Wb}$

$\mathrm{WbHkZw}_{1} \mathrm{Zw}_{2} \mathrm{BgMlPr}_{3}$

$\mathrm{WbKn}_{I} \mathrm{Ad}_{2}$

$K n_{1}[112 r] A q \ldots ?$

$K n_{1}$

lectio unica, gregs cum signo abbrev. $K n_{1}[112 r]$ (gregoris Karwasińska legit)

$L l R v_{2} \mathrm{WbKn}_{I} A q$

$K n_{1} A d_{2}$

$K n_{1}$

omnes praeter $L s$

$W b Z w_{1} W d K n_{1} K n_{2} A d_{2} B b$

lectio unica

omnes praeter $L s G n$

lectio unica

omnes praeter LsLlRv ${ }_{2} A q$

lectio unica

$\mathrm{Kn}_{2} \mathrm{St} \mathrm{t}^{65}$

omnes praeter Ls

$K n_{1}$

$R v_{2} \mathrm{ZfHkMlKn_{1 }} \mathrm{Kn}_{2} \mathrm{BbPr}_{3} \mathrm{TrStAq}$

$R v_{2} H k Z w_{1} W d M l K n_{2} A q$, corr. $e$ prouolutis $L l K n_{1}$

${ }^{65}$ Posiadany mikrofilm nie umożliwia weryfikacji lekcji $K n_{1}$ w tym miejscu (ira, według edycji, VA I/A, cap. 15, s. 22). 
Ip.

153 22, 10: profudit

154 23, 1: incolunt

155 23, 2: Deo

156 23, 3: cohabitaueris

157 23, 4: accipe

158 23, 12: prefuissset (sic)

159 23, 14: Postquam ingressus

160 23, 14: datur copia

161 23, 15: abba

162 23, 16: prius quam

$16323,18-24,1$ : et dura illi

164 24, 5: illum

165 24, 11: uinclis

166 24, 15: clipeo

167 24, 16: monachatum

168 25, 4: spiritalibus

169 25, 6: floruit

170 25, 8: donauit eum suus abbas

171 25, 8: erat

172 25, 10: se

17325,12 : testacia

174 25, 15: fierent

175 25, 17: foret

176 25, 17: corruit ipse

177 26, 1: aduersitas comitaretur

178 26, 2: repperitur

17926,2 : facta foret

180 26, 4: iussa

18126,4 : foret

182 26, 5: profitetur

183 26, 5-6: adhesisse ei

184 26, 6: signaculum

185 26, 16: eius imperio

186 26, 16: abscessit

187 26, 18: Mogontinus

188 27, 1: factaque

189 27, 2-3: eorum

190 27, 4-5: inuicem pugnantibus sententiis utraque pars diu
Rękopisy o lekcji zgodnej lub podobnej do $\mathrm{Hb}$

$\begin{array}{ll}\text { 239vb: prodit } & K n_{1}[112 v] \\ \text { 239vb: colunt } & K n_{1}[112 v] \\ \text { 239vb: deest } & \text { lectio unica } \\ \text { 239vb: habitaueris } & M l K n_{1} \mathrm{Kn}_{2} A d_{2} \\ \text { 239vb: audi } & K n_{1}\end{array}$

\section{caput 16}

239vb: preesset

lectio unica

240ra: postquam autem i. $\quad K n_{I} A d_{2}$

240ra: copia datur

$\mathrm{WbKn}_{1} A d_{2}$

240ra: abbas (s suprascr.)

240ra: priusquam

omnes praeter Ls

240ra: illi et dura

240ra: deest

240ra: vinculis

240ra: clippeo

240rb: monasticam

$K n_{1}[113 r] A q \ldots$ ?

$K n_{1} A d_{2}$

lectio unica

LlZfHkZw ${ }_{1} W d M l K n_{1} T r O s$

$W b K n_{l} B b$

lectio unica, monachicam $K n_{1}$ et alii multi

\section{caput 17}

240rb: spiritualibus

240rb: refloruit

240rb: eum donauit abbas suus

240rb: fuit

240rb: sese

240rb: testea

240rb: faceret

240rb: esset

240rb: ipse corruit

240va: comitaretur aduersitas

240va: reperitur

240va: foret facta

240va: deest

240va: vellet

240va: professa est

240va: ei adhesisse

240va: signaculum ei

240va: eius ab imperio

240va: discessit

\section{caput 18}

240va: Maguntinus

omnes praeter LsZfWbAq

WbHkZw ${ }_{1} W d M l K n_{1} K_{2} A d_{2}$

$H k Z w_{1} W d M l K n_{1} K_{2} A d_{2}$

$K n_{1}$

$H k Z w_{1} W d K n_{1} K n_{2}$

$\mathrm{UtHkZw}{ }_{2} \mathrm{BgKn}_{\mathrm{I}} \mathrm{Pr}_{2} \mathrm{Pr}_{3} \mathrm{TrStOS}$

$K n_{1}$

LlUtKn,

$H k Z w_{1} M l K n_{1}$

lectio unica

$K n_{1}[113 v] \ldots ?$

$H k Z w_{1} Z w_{2} W d M l K n_{1} K_{2} A d_{2} O s A q$

$H k Z w_{1} W d M l K n_{1} K n_{2} A d_{2}$

uellet scriptum supra del. foret $K n_{1}$

$H k Z w_{1} W d M l K n_{1} K_{2} A d_{2}$

Ll

lectio unica

$\mathrm{Kn}_{1}$

lectio unica (abcessit $K n_{1}[114 r]$ )

$R v_{2} \mathrm{Kn}_{2} \mathrm{Pr}_{3} \mathrm{TrStGn}$

240va: ffacta

$\mathrm{WbHkZw}_{1} \mathrm{Zw}_{2} \mathrm{WdMlKn_{1 }} \mathrm{Kn}_{2} \mathrm{Ad}{ }_{2} \mathrm{Os}$

240vb: deest

Gn

240vb: diu p. s. vtraque pars inuicem lectio unica 
Ip.

VA I/A, strona, wiersz

191 27, 12: dicta

192 28, 3: gauderent

193 28, 3: priorem uitam

194 29, 8: Clauim

195 29, 10: quoque

196 29, 11: ut se

197

198

199 29, 12: fructus

200 29, 14: uoluit

201 29, 14: Uuillico

202 30, 3: et cursu

203 30, 4: gressu

204 30, 11: dilatrauit

205 30, 14: affatibus

206 30, 14: in manus

207 30, 15: mortis timore

208 30, 16: cruentis

209 30, 16: prodidit

21030,19 : male usi

211 30, 22: contra ire

212 31, 5: sed

213 31, 8: cupiuerat

214 31, 9: abba

215 31, 10: uere

216 31, 10: erat

217 32, 1: homine narrat

218 32, 1-2: huiusmodi hominem

219 32, 3: se promittit

$220 \quad 32,7$ : prima

221 32, 11: Suus

222 32, 11: diebus pontifex

223 32, 12: sua

224 32, 12: dimisit

225 33, 2: incommodorum

226 33, 3: nomine Bruno

227 33, 4: regio
$H b$, karta, strona, kolumna

240vb: deest

240vb: gauderent et

240vb: priorem eius vitam

\section{caput 19}

241ra: Clauem

241ra: vero

241ra: ut quasi per se

241ra: auctorem

241ra: pro

241ra: fructibus

241ra: uolebat

241ra: willico

241rb: deest

241rb: cursu

241rb: delatrauit

241rb: fatibus

241rb: deest

241rb: timore mortis

241rb: cruentibus

241rb: tradidit

241rb: maleusi

\section{caput 20}

241va: contraire

241va: et

241va: concupiuerat

241va: abbas

241va: deest

241va: est

241va: narrat homine

$241 \mathrm{vb}$ : hominem huiusmodi

241vb: se ei promittit

\section{caput 21}

241vb: deest

241vb: Suis

241vb: diebus summus $\mathrm{p}$.

241vb: duo

241vb: diuisit

241vb: incomodorum

241vb: Bruno nomine

241vb: eregio
Rękopisy o lekcji zgodnej lub podobnej do $\mathrm{Hb}$

$\mathrm{Kn} n_{1}$
$\mathrm{LlRv}{ }_{2} \mathrm{WbHkZw} w_{1} \mathrm{WdMlKn}{ }_{1} \mathrm{Kn}_{2} \mathrm{Pr}_{3}$
$\mathrm{TrOsGnAq}$
$\mathrm{Kn}$

$K n_{1}$

$\mathrm{ZfZ} w_{1} \mathrm{Zw}{ }_{2} \mathrm{BgPr}_{2} \mathrm{Pr}_{3} \mathrm{TrStOS}$

lectio unica

lectio unica, ut ut [sic] quasi per se $K n_{1}[114 v]$

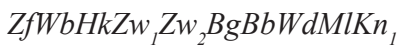
$\mathrm{Kn}_{2} \mathrm{Ad}_{2} \mathrm{Pr}_{3} \mathrm{Tr}$

omnes praeter $L s L l R v_{2} A q$

omnes praeter $L s L l R v_{2} A q$

$H k Z w_{1} W d M l K n_{1} K n_{2} A d_{2}$

ZfWbHkZw ${ }_{1} W d M l K n_{1} K n_{2} A d_{2}$

$H k Z w_{1} W d M l K n_{1} K n_{2} A d_{2}$

$K n_{1}$

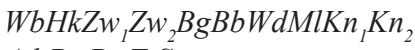
$\mathrm{Ad}_{2} \mathrm{Pr}_{2} \mathrm{Pr}_{3} \mathrm{TrSt}$

$K n_{1}$

lectio unica (longius fragmentum deest AqLIRv ${ }_{2}$ )

lectio unica

$\mathrm{BgWdKn_{1 }} \mathrm{Kn}_{2} \mathrm{Os}$

$H k Z w_{1} W d M l K n_{1} K n_{2} A d_{2}$

lectio unica? (male usi $K n_{l}$ )

lectio unica? (contra ire $K n_{1}$ )

$H k Z w_{1} W d M l K n_{1} K_{2} A d_{2}$

$\mathrm{Kn}_{1}[115 \mathrm{r}] \mathrm{ZAAd} \mathrm{Gn}_{2}$

$\mathrm{Rv}_{2} \mathrm{ZfZ} w_{2} \mathrm{BgBbPr}_{2} \mathrm{Pr}_{3} \operatorname{TrOsAq}_{\mathrm{A}}$

$\mathrm{Kn}{ }_{1}[115 r]$

$K n_{1}$

$H k Z w_{1} W d M l K n_{1} K n_{2}$

$Z w_{1} W d M l K n_{1} K n_{2} A d_{2}$

$H k Z w_{1} W d M l K n_{1} K n_{2} A d_{2}$

$\mathrm{WbHkZw}_{1} \mathrm{WdMlKn}_{1} \mathrm{Kn}_{2} A d_{2}$ $\mathrm{Kn}_{1} \mathrm{Pr}_{3} \mathrm{Gn}$, Summus $\mathrm{Pr}_{2} \mathrm{TrOS}$ lectio unica, $c f$. supra

lectio unica

LsLlKn ${ }_{1} \mathrm{Pr}_{3} \mathrm{TrSt}$

lectio unica? (incommodorum $K n_{1}$ )

$A q$

$H k Z w_{1} W d M l A d_{2}$, e regio $K n_{1}[115 v]$ 
Ip.

$$
\text { VA I/A, strona, wiersz }
$$

228 33, 5: scilicet

229 33, 6: Magontinus

230 33, 6: Uuilgisus

231 33, 7: Ildebaldus

23233,8 : acceptum

233 33, 10: imperatorum

234 33, 10: attigit apicem

235 33, 14: ille cęsar

236 33, 18: Uuilgisus

237 33, 18-34, 1: domnum apostolicum de sancti hominis reditu

238 34, 2: modis omnibus

239 34, 3: iusta

240 34, 5: poscentibus

241 34, 6: uersus

242 34, 9: relinquere

243 34, 10: quisset

244 34, 16: Cumque duorum

245 34, 17: Italicis

246 35, 1: mansit bonum

247 35, 2: dulcissimus

248 35, 8: exhibere

249 35, 8: monstrare

250 35, 9: timere

251 35, 9: amare

252 35, 10: pensare

253 35, 12: bene agentibus

254 35, 13: plura

255 35, 14: electionem

256 35, 16: regia domo

257 35, 16: seruiens

258 36, 1: eorum

259 36, 4: abluit

260 36, 4: purgatas

261 36, 6: pro

262 36, 7: Uolpharius

263 36, 7: imperialis
$H b$, karta, strona, kolumna

241vb: deest

241vb: maguntinus

241vb: Willegisus

241vb: hildebaldus

242ra: susceptum

242ra: imperatorium

242ra: apicem attigit

\section{caput 22}

242ra: cesar ille

242ra: Willegisus

242ra: deest

242ra: omnibus modis

242ra: iuste

242ra: petentibus

242ra: reuersus

242ra: linquere

242ra: quisset post del. posset

\section{caput 23}

242rb: Cumque velut duorum

242rb: ytalicis

242rb: bonum mansit

242rb: sanctissimus

242rb: exhiberet

242rb: monstraret

242rb: timeret

242rb: amaret

242rb: pensaret

242rb: beneagentibus

242rb: cuncta

242rb: gloriam

242va: domo regia

242va: seruus

242va: illorum

242va: lauit

242va: purgatis sordibus

242va: pre

242va: wolfarius nomine

242va: regis imperialis

Rękopisy o lekcji zgodnej lub podobnej do $\mathrm{Hb}$

\author{
WbMlKn${ }_{I} A d_{2}$ \\ $A q$ \\ $H k Z w_{1} W d M l K n_{I} A d_{2}$ \\ $\mathrm{Kn}_{1}[116 r] L l R v_{2} \mathrm{Zw}{ }_{1} \mathrm{WdKn}{ }_{2} \mathrm{Cr}$ \\ $H k Z w_{1} W d M l K n_{1} K n_{2} A d_{2}$ \\ $H k Z w_{1} W d M l K n_{1} A_{2}{ }_{2} T r O s$
}

lectio unica

$K n_{1}$

$\mathrm{Kn}_{1}[116 r] A d_{2}$

LsLlRv ${ }_{2} W b H k Z w_{1} W d M l K n_{1} K n_{2} A d_{2} A q$

$W b H k Z w_{1} W d M l K n_{1} K_{2} A d_{2}$

WbHkZw ${ }_{1} W d M l K n_{1} \mathrm{Kn}_{2} \mathrm{Ad}{ }_{2} \mathrm{CrGn}$

$\mathrm{HkZw_{1 }}$ WdMlKn$n_{1} \mathrm{Kn}_{2} \mathrm{Ad}{ }_{2} \mathrm{Cr}$

lectio unica

$\mathrm{WbHkZw}_{1} \mathrm{WdMlKn}_{1} \mathrm{Kn}_{2} \mathrm{Ad}{ }_{2}$ quisset $K n_{1}$ et alii plurimi, $c f$. posset $\mathrm{HkPr}_{3} \mathrm{Tr}$

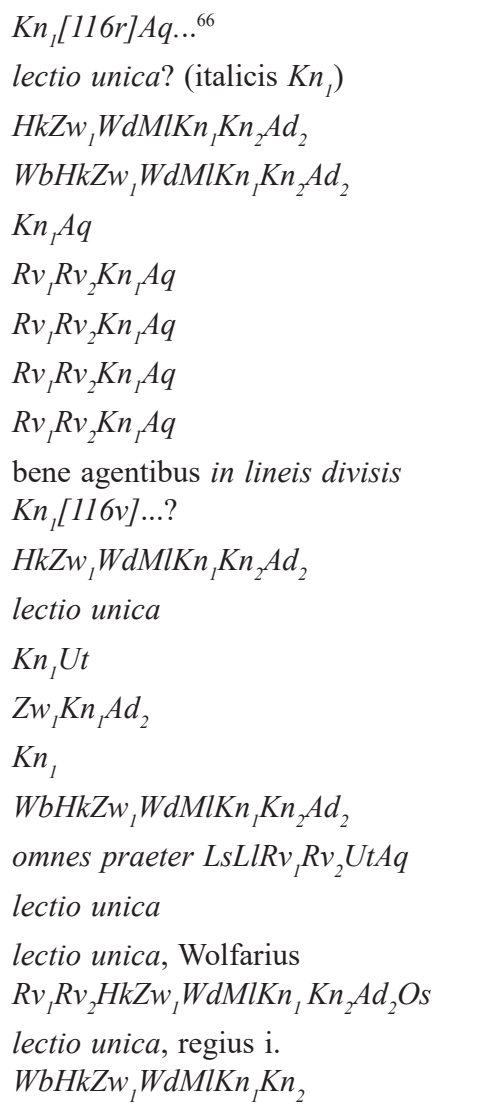

${ }^{66}$ Słowo velut prawdopodobnie wyłącznie przez pomyłkę wypadło z tekstu edycji J. Karwasińskiej, por. C. Gaşpar, VA, s. 158. 
Ip.

VA I/A, strona, wiersz

$H b$, karta, strona, kolumna

\section{caput 24}

264 36, 10: quoque

26536 , 10: ibi somnium

266 36, 11: et media

26736,14 : lectulus

268 36, 17: auctentum

269 37, 2: secundante

270 37, 5: sancto sanctorum

271 37, 6: et prona

272 37, 7: Gloria

273 37, 8: humillimum

274 37, 10: Turoniam

275 37, 11: qui

276 37, 13: sit Domino

277 37, 14: karissimorum

278 37, 16: menti

279 37, 16: agere uellet

280 37, 17: familiarem extremum

281 37, 18: inuicem

282 37, 21: quod

283 38, 2: etiam eius

284 38, 2: magnam

285 38, 3: barbaris

286 38, 5: gratiam

287 38, 5: conferre

288 38, 6: nefas

289 38, 8: morte seuissima

29038 , 10: suis fratribus

291 38, 11: Bolizlauo

292 38, 11: Palaniorum

293 38, 11: foras

294 38, 15: esse

295 39, 4: amicus

296 39, 5: Tantum ac talem

297 39, 6: nouum 242va: itaque

242va: sompnium sibi

242va: et in media

242va: lectus

242va: autentum

242vb: fecundante

242vb: sanctorum sancto

242vb: prona

242vb: Gracias

242vb: humilimum

\section{caput 25}

242vb: turonam

242vb: que

242vb: sit coram domino

242vb: sacratissimorum

242vb: mentis

242vb: ageret

242vb: familiarem et e.

242vb: deest

242vb: quia

243ra: eius eciam

243ra: multam

243ra: barbarismo

243ra: gracia

243ra: conferri

243ra: nephas

243ra: seuissima morte

243ra: fratribus suis

243ra: bolezlao

243ra: polonorum

243ra: deest

\section{caput 26}

243ra: iter

243ra: deest

243ra: Talem ac tantum

243ra: deest
Rękopisy o lekcji zgodnej lub podobnej do $\mathrm{Hb}$

lectio unica

lectio unica, sibi somnium $K n_{l}$, sompnium ibi $R v_{1} R v_{2}$

$\mathrm{Zw}_{2} \mathrm{BgKn}_{1} \mathrm{Pr}_{2} \mathrm{Pr}_{3} \mathrm{TrStCr}$

$\mathrm{WbHkZw}_{1} \mathrm{WdMlKn}_{1} \mathrm{Kn}_{2} \mathrm{Ad}_{2}$

$B g$, auctentum sed c l. partim del. $K n_{1}[117 r]$

ZfWbHkZw ${ }_{1} W d M l K n_{1} \mathrm{Kn}_{2} \mathrm{Ad}_{2} \mathrm{Pr}_{2} \mathrm{St}$

$\mathrm{WbHkZw}_{1} \mathrm{WdMlKn}_{1} \mathrm{Kn}_{2} \mathrm{Ad}{ }_{2}$

$K n_{1}[117 r] A q \ldots{ }^{67}$

$\mathrm{WbHkZw}_{1} \mathrm{WdMlKn}_{1} \mathrm{Kn}_{2} \mathrm{Ad}{ }_{2}$

lectio unica

$R v_{1} R v_{2} \mathrm{Kn}_{1} \mathrm{Ad}_{2} \mathrm{Os}$

omnes preater $L s L l R v_{1} R v_{2} O s A q$ (q cum signo abbrev. ZfMlPr $\mathrm{St}$ )

lectio unica

lectio unica

$\mathrm{Kn}{ }_{1} \mathrm{GnCr}$

$H k Z w_{1} W d M l K n_{1} K n_{2} A d_{2}$ $\mathrm{WbHkZw}_{1} \mathrm{WdMlKn}_{1}[117 r] \mathrm{Kn}_{2} \mathrm{Ad}_{2}$ $\mathrm{Kn}_{1} \mathrm{Pr}_{2}$ omnes praeter LsLlRv $v_{1} v_{2} C r A q$ $K n_{1}$ $H k Z w_{1} W d M l K n_{1} K n_{2} A d_{2}$ WbHkZw ${ }_{1} W d M l K n_{l} A d_{2}$ LlWbHkZw ${ }_{1}$ WdMlKn $n_{1}[117 r]$ $\mathrm{Kn}_{2} \mathrm{Ad} d_{2} \mathrm{Aq}$, corr. in gratiam $\mathrm{Ls}$ LlKn

lectio unica? (nefas $K n_{l}$ )

lectio unica

$\mathrm{ZfCr}$

$W b H k Z w_{1} W d K n_{1} K n_{2} A d_{2} O s$

$\mathrm{StOsCrGn}$

WbHkZw ${ }_{1} \mathrm{WdMlKn} n_{1} \mathrm{Kn}_{2} \mathrm{Ad}{ }_{2}$ $W b H k Z w_{1} W d M l K n_{1} K n_{2} A d_{2}$ $K n_{1}$ omnes praeter $L s L l R v_{1} R v_{2} Z f A q$ omnes praeter $L s L I R v_{1} R v_{2} Z f A q$

${ }^{67}$ Słówko et w tym miejscu wydaje się pomyłką edytorki, por. C. Gaşpar, VA, s. 162. 
Ip.

298 39, 7-8: Agnoscimus

299 39, 9: uenit

300 39, 10: quę fratribus

30139,12 : beatus

302 39, 13: excederet

303 40, 3: desiderio

304 40, 3: declinant

305 40, 6: postmodum

306 40, 7: Liuticenses

307 40, 9: cum morte

308 40, 11: Pruzię

309 40, 12: ter deno

310 40, 13: Gyddanyzc

311 41, 4: seruabat

312 41, 6: carine et

313 41, 8: litus

314 41, 11-12: Gaudentius

315 41, 14: pugnis

316 41, 16: Excussus

317 42, 3: etsi

318 42, 4: sabbato

319 42, 5: transduxit

320 42, 6: furibundo

321 42, 8: ueniret

322 42, 8: talia

323 42, 11: nostri itineris

324 42, 13-14: inmarcessibilibus

325 42, 16: Et

326 42, 16-17: extimplo

327 42, 17: percutientes

328 42, 17: apponunt

329 42, 19: spem uitę

330 43, 1: toto

$33143,1-2$ : communis

332 43, 2: legis

333 43, 3: uero

334 43, 4: nauiculam
$H b$, karta, strona, kolumna

Rękopisy o lekcji zgodnej lub podobnej do $\mathrm{Hb}$

243ra: Agnouimus agnouimus

$K n_{1}$

243rb: ueniet

$L l R v_{1} R v_{2} K n_{1} S t O s$

243rb: que de fratribus

$\mathrm{ZfWbHkZw_{2 }} \mathrm{BgBbMlKn}{ }_{1}$ $\mathrm{Kn}_{2} \mathrm{Ad}_{2} \mathrm{Pr}_{2} \mathrm{Pr}_{3} \mathrm{Cr}$

243rb: illusus

$\mathrm{Zw} \mathrm{Zw}_{2} \mathrm{BgBbWdMlKn_{1 }}$ $\mathrm{Kn}_{2} \mathrm{Ad}_{2} \mathrm{Pr}_{2} \mathrm{Pr}_{3} \mathrm{TrSt}$

243rb: excideret

$\mathrm{Kn}{ }_{1}$

243rb: desideria

243rb: declinant perdicionis

$$
\text { omnes praeter LsLlRv }{ }_{1} R v_{2} Z f A q
$$

lectio unica

\section{caput 27}

243rb: post

omnes praeter $L s L l R v_{1} R v_{2} Z f G n A q$

243rb: lucienses

243rb: cum morte est

243rb: pruzzie

$K n_{1}$

$\mathrm{WbHkZw}_{1} \mathrm{WdMlKn}_{1} \mathrm{Kn}_{2} A d_{2}$ pruzzię $L l Z f$

243rb: terdeno

lectio unica? (ter deno $K n_{1}$ )

243rb: Ginadic

243va: seruauit

$H k Z w_{1} W d M l K n_{1} K_{2} A d_{2}$

$\mathrm{ZfWbHkZw_{1 }} W d M l K n_{1} \mathrm{Kn}_{2} \mathrm{Ad} \mathrm{Cr}_{2}$

\section{caput 28}

243va: deest

$K n_{1}[118 r]$

243va: littus

lectio unica? (litus $K n_{l}$ )

243va: gaudencius

lectio unica? (Gaudentius $K n_{1}$ )

243va: pugnis cum signo abbrev., pro lectio unica pungnis?

243va: Excussusque

lectio unica

243va: et si

$K n_{1}[118 r] A q \ldots$ ?

243va: subto (sic)

lectio unica

243va: transuehit

243vb: furibunda voce

243vb: venisset

243vb: tali

243vb: itineris nostri

243vb: īmarcescibilibus

243vb: deest

243vb: Ex timplo

243vb: percuciunt

243vb: opponunt

243vb: deest

$K n_{1}$

omnes praeter $L s L l R v_{1} R v_{2} Z f G n A q$

lectio unica

omnes praeter LsLlRv $v_{1} R v_{2} Z f G n A q$

$K n_{1}$

inmarcescibilibus (uel imm-) omnes praeter $L s R v_{1} R v_{2} B b G n P r_{3} T r A q$

omnes praeter LsLlRv ${ }_{1} R v_{2} A q$

$K n_{1}[118 v] A q \ldots$ ?

omnes praeter $L s L l R v_{1} R v_{2} Z f A q$

lectio unica

lectio unica

$R v_{1} R v_{2}$

lectio unica

243vb: commuis

243vb: plebis

$H k Z w_{1} W d M l K n_{1} K_{2} A d_{2}$

243vb: deest

243vb: nauicule omnes praeter LsLlRv $v_{1} v_{2} \mathrm{ZfCrGnAq}$

omnes praeter LsLIRv ${ }_{1} v_{2} \operatorname{Pr}_{3} T r A q$ 
Ip.

VA I/A, strona, wiersz

$H b$, karta, strona, kolumna

\section{caput 29}

\begin{tabular}{|c|c|}
\hline 345 & $45,1:$ sole ascendente \\
\hline 346 & 45, 5: cespite \\
\hline 347 & 45,5 : iactus est lapidis \\
\hline 348 & 45, 6: Hic cępit \\
\hline 349 & 45,7 : profudit \\
\hline 350 & 45,7 : soporifera \\
\hline 351 & 45,8 : pausantibus \\
\hline 352 & 45, 9: iniecerunt \\
\hline 353 & 45, 9: omnes \\
\hline 354 & $45,14: \mathrm{e}$ \\
\hline 355 & $45,14-46,1:$ Sicco \\
\hline 356 & 46,2 : cohortis \\
\hline 357 & 46, 3: concurrerunt \\
\hline 358 & 46, 5: Exiit \\
\hline 359 & 46, 8: Dominum \\
\hline 360 & 46,10 : carissimo tandem \\
\hline 361 & 46,11 : cuius uultu \\
\hline 362 & 46,12 : dignissimum \\
\hline 363 & 46,13 : portauit \\
\hline 364 & 47,1 : armis dira barbaries \\
\hline 365 & 47, 6: VIIII \\
\hline 366 & 47, 6: Mai \\
\hline 367 & 47, 6: Ottonum \\
\hline & 47, 7: VI \\
\hline & 47, 8: pro Deo suo \\
\hline
\end{tabular}

243vb: illa

243vb: deest

244ra: velocissimo

244ra: transnant

244ra: vero

244ra: fratrem

244ra: respondente

244ra: ipso

244ra: deest

244ra: deest

\section{caput 30}

244rb: ascendente sole 244rb: potius cespice 244rb: est iactus lapidis 244rb: hic cum cepit

244rb: perfudit

244rb: sopifera

244rb: pulsantibus

244rb: iecerunt

244rb: eos

244rb: ex

244rb: siggo

244rb: plebis

244rb: concurrunt

244rb: Exit

244va: deum

244va: tandem karissimo

244va: cuius in wltu

244va: dignum

244va: deest

244va: dira barbaries armis

244va: IX

244va: aprilis

244va: Ottone

244va: sexta

244va: deest
Rękopisy o lekcji zgodnej lub podobnej do $\mathrm{Hb}$
$H k Z w_{1} M l K n_{1} \mathrm{Kn}_{2} A d_{2}$

lectio unica

$R v_{1} R v_{2} Z w_{2} B g K n_{I} A q$

$\mathrm{Pr}_{3} \mathrm{TrStOs}$, h. tum c.

WbHkZw ${ }_{2} \mathrm{BgBbWdMlKn_{1 }} \mathrm{Kn}_{2} \mathrm{Ad}_{2} \mathrm{Pr}_{2}$ omnes praeter LsLlZfPr

$K n_{1}$

$R v_{1} R v_{2} P r_{3}$

$\mathrm{WbHkZw}_{1} \mathrm{MlKn}_{1} \mathrm{Ad}_{2} \mathrm{Os}$

lectio unica

omnes praeter LsSt

$\mathrm{WbHkZw}_{1} \mathrm{Zw} \mathrm{BgBbWdMlKn}_{1}$

$\mathrm{Kn}_{2} \mathrm{Ad}_{2} \mathrm{Pr}_{2} \mathrm{Pr}_{3}$

$H k Z w_{1} W d M l K n_{1} K n_{2} A d_{2}$

$\mathrm{WbHkZw}_{1} \mathrm{Zw}_{2} \mathrm{BgBbMlKn_{1 }}$ $\mathrm{Kn}_{2} \mathrm{Ad}_{2} \mathrm{Pr}_{2} \mathrm{Pr}_{3} \mathrm{Tr}$

Os

$W d K n_{1} K n_{2}$

$K n_{1}$

omnes praeter

$\mathrm{LsZw}_{2} \mathrm{BgBbPr}_{2} \mathrm{Pr}_{3} \mathrm{TrStCr}$

$K n_{1}$

$\mathrm{WbHkZw}_{2} \mathrm{WdMlKn_{1 }} \mathrm{Kn}_{2} \mathrm{Ad}_{2} \mathrm{Pr}_{2} \mathrm{Pr}_{3} \mathrm{Tr}$

lectio unica

lectio unica? (VIIII $K n_{l}$ )

$L s W g R v_{1} R v_{2} H k Z w_{1} W d M l K n_{1} K n_{2}$ $\mathrm{Kn}_{1}[119 v] \mathrm{WgRv}{ }_{1} \mathrm{WbBbMlKn}_{2} \mathrm{Pr}_{3}$ $\mathrm{TrStCr}$

$\mathrm{Kn}{ }_{1}[119 v] \mathrm{WgSt}$

$H k Z w_{1} W d M l K n_{1} K n_{2} A d_{2}$ 


\section{Aneks 2}

\section{Pozostałe lekcje różne $\boldsymbol{H b}$ i $K n_{1}^{68}$}

\begin{tabular}{|c|c|c|c|}
\hline Ip. & VA I/A, strona, wiersz & $H b$, karta, strona, kolumna & $K n_{l}$, karta, strona \\
\hline 1 & 4, 4: toti populo & 236ra: toti populo & 107r: toto populo \\
\hline 2 & $5,9:$ fratres & 236rb: fratres & $107 \mathrm{v}$ : fratris \\
\hline 3 & 5, 15: extenuato & 236rb: extenuato & $107 \mathrm{v}$ : ex tenuato $(\mathrm{sic})$ \\
\hline 4 & 8, 11: scolares & 236vb: scolares & 108v: sculares \\
\hline 5 & 15, 8: quot & 238ra: quot & 110v: quod \\
\hline 6 & 15, 9: quot & 238ra: quot & 110v: quod \\
\hline 7 & 15, 16: quid & 238rb: quid & 110v: quit \\
\hline 8 & 17, 10: seuiens & 238va: seuiens & 111r: seruiens, $l$. r partim del. \\
\hline 9 & 18, 7: Iudeus & 238vb: iudeus & 111r: uidens \\
\hline 10 & 19, 9: regio & 239ra: regio & $111 \mathrm{v}$ : regia \\
\hline 11 & 21, 17: attonitas & 239va: attonitas & $112 \mathrm{v}$ : antonitas \\
\hline 12 & 23, 13: inquirens & 239vb: inquirens & 113r: requirens \\
\hline 13 & 29, 8: Georgii & 241ra: Georgii & 114r: Georgi \\
\hline 14 & 29, 17: defendere & 241ra: defendere & $114 \mathrm{v}$ : desfendere \\
\hline 15 & $33,1:$ domini & 241vb: domini & $115 \mathrm{v}$ : domni \\
\hline 16 & 33, 3: clericus nomine Bruno & 241vb: clericus Bruno nomine & 115v: clericus Bruno \\
\hline 17 & 34, 16: Magunciam & 242rb: magunciam & 116r: magontiam \\
\hline 18 & 35,2 : imperiali & 242rb: imperiali & 116v: imperali \\
\hline 19 & 39,3 : furoris & 243ra: furoris & $117 \mathrm{v}$ : feruoris \\
\hline 20 & 40, 14: dirimentem & 243rb: dirimentem & $\begin{array}{l}\text { 118r: dirimentum corr. ex dirimenteim } \\
\text { (secundum Karwasińska) }\end{array}$ \\
\hline 21 & 44, 12: mihi & 244ra: michi & 119r: minhi \\
\hline 22 & 44, 13: nec mihi nec alicui & 244ra: nec michi nec alicui & 119r: nec michi alicui \\
\hline 23 & 44, 19: Iam & 244ra: Iam & $\begin{array}{l}\text { 119r: am (ut videtur in spe initialis i } l \text {. } \\
\text { adscribendae) }\end{array}$ \\
\hline 24 & 45, 14: uitam & 244rb: vitam & 119v: uitamur (sic) \\
\hline
\end{tabular}

${ }^{68} \mathrm{~W}$ zestawieniu wyszczególniono tylko różnice, które nie wynikają ze wskazówek w ostatniej kolumnie wykazu w Aneksie 1. Poza wskazanymi w przyp. 62 zignorowano również następujące oboczności: menb-/memb-; app-/adp-; imm-/inm-; ab-/adb-; agg-/adg-; lit-/litt-. Nie uwzględniono też innych banalnych odmianek związanych z łączną/rozłączną pisownią wyrazów (Kn, ma np. Oter w miejsce $O$ ter). 


\section{Aneks 3}

\section{Lekcje $K n_{1}-$ uzupelnienia i poprawki do edycji ${ }^{69}$}

Lekcja $K n_{I}$ według edycji J. Karwasińskiej ${ }^{70}$

4, 4: precepta

4, 4: toti

4, 15: procreauerant

5, 15: extenuato

6, 2: Adalbertum

6, 21, adn. b: gessit pr., postea al. m. suprascr. rexit

7, 8: domicilia confugit

8, 11: concurrunt

8, 11: scolares

8, 11: quidnam

8, 12: quia

8, 22: erat pater

11, 13: ęcclesia

11, 36, adn. m: et

12, 15: adquiescens

12, 29, adn. $b$ : saracinico

13, 9: consumans

14, 34, adn. q: alīqd

15, 15: monachicę

16, 14: cumque

16, 21, adn. $h$ : autem

17, 10: seuiens

17, 14: captiuitate

18, 38-39, adn. k: Williconen adscr. in marg.

18, 41, adn. $s$ - $t$ : esse participem

19, 2, cum adn. e, f-g: menbra mouemur et sumus

20, 12: Casinum

20, 41, adn. e: gregoris

21, 29, adn. b: ut

22, 10: profudit

23, 1: incolunt

23, 16: prius quam

$25,37, a d n . m$ : testea

26, 2: repperitur

26, 16: abscessit
Rzeczywista lekcja $K n_{1}$ 107r: preceptum

107r: toto

$107 \mathrm{v}$ : procreauerat

107v: ex tenuato (sic)

107v: Adelbertum

108r: rexit

108r: confugit domicilia

108v: concurrerunt

108v: sculares (sic)

108v: quid nam in lineis divisis

108v: qui

$108 \mathrm{v}$ : erat eius pater

109v: ecclesiam

109r: ac

$109 \mathrm{v}$ : acquiescens

109v: sarracinico

110r: consummans

110r: aliquod

110v: monastice

111r: eumque

110v: aut, in fine verbi l. erasa: $\overline{\mathrm{e}}$ ?

111r: seruiens sed $\mathrm{r}$ l. partim del.

111r: ultima pars verbi del.

$111 \mathrm{v}$ : Williconem adscr. in marg.

$111 \mathrm{v}$ : esse participem fecit

$111 \mathrm{v}$ : menbra a quo mouemur et sumus

112r: cassinum

112r: potius gregorius (gregs cum signo abbrev.)

112r: sicut

112v: prodit

$112 \mathrm{v}$ : colunt

113r: priusquam

$113 \mathrm{v}$ : testea, ante -ea duae litterae erasae

$113 \mathrm{v}$ : reperitur

114r: abcessit

${ }^{69}$ Pominięto oboczności wymienione w przyp. 62 i 68, a także (z pewnymi wyjątkami) informacje o poprawkach i uzupełnieniach nanoszonych ex post przez skrybę oraz innych osobliwościach (np. uszkodzeniach) rękopisu, których edycja J. Karwasińskiej nie sygnalizuje. Pojawiające się tu i ówdzie zaplamienia mogą być zresztą późne lub nawet występować wyłącznie na wykorzystanym mikrofilmie.

${ }^{70}$ Uwzględniono też sytuacje, w których lekcja $K n_{1}$ nie została w sposób jasny podana w edycji (lekcja wskazana w lewej kolumnie tabeli jest w takim przypadku zgodna z głównym tekstem wydania). 


\section{Lekcja $K n_{1}$ według edycji J. Karwasińskiej}

29, 8: Georgii (in adn. e lectio Kn, erronee cum sig. Kn, indicata)

29, 11: ut per se (adn. r-r: per cum signo inseren. adscr. in marg.)

29, 17: defendere

30,14 cum adn. $g$ - $h$ : nunc fatibus

31, 2: dulcis

31, 8: cupiuerat

31, 10: uere

31, 13 cum adn. $g$ - $h$ : monstrat ei duos

33, 7: Ildebaldus

$33,24, a d n . r$. eregio

$33,43, a d n$. l: villegisus

34, 8: domnus

34, 16: Cumque duorum

35, 2: imperiali

35,12 : bene agentibus

$35,30, a d n . j$ : monstraret

35, 31, adn. l: timeret

$35,32, a d n$. $r$ : amaret

35, 33, adn. $u$ : pensaret

35, 33, adn. v-v: est

$35,40, a d n$. $n$ : seruitute

36, 17: auctentum

37, 6: sedet, et prona

37, 17: familiarem extremum

38, 5: gratiam

39, 35-36, adn. $h$ : Dirupisti

40, $1 \mathrm{cum}$ adn. e-e: uirtutis et te ęternę

41, 28, adn. $b$ : salutis

41, 6 cum adn. $d$ : inponitur et pelago (post inponitur vacuum pro 3-4 litteris)

42, 3: etsi

42, 4: Transiens

42, 4 cum adn. $q$ : stetit sabbato

42, 12-13 cum adn. a: est; ut

42, 16-17: extimplo

44, 3: domnus

44, 12: mihi

44, 19: Iam

45, 14: uitam

47, 6: Ottonum

47, 7: VI

\section{Rzeczywista lekcja $K n$}

114v: Georgi

$114 \mathrm{v}$ : ut ut quasi per se (post primum ut signum inserendi, in marg. repetitum cum verbis ut quasi per, i.e. cum verbo ut erronee iterato)

$114 \mathrm{v}$ : desfendere (prius descendere post $\mathrm{c}$ l. in f corr.)

115r: nunc amicis fatibus

115r: dulcis ( $l .1$ post inserta)

115r: concupiuerat

115r: deest

$115 \mathrm{v}$ : monstrat ei per uisum duos

116r: hildebaldus (l. h suprascr.)

$115 \mathrm{v}$ : e regio (i.e. eregio post lineis separatum)

116r: willegisus

116r: dns cum signo abbrev.

116r: Cumque uelut duorum

116v: imperali (sic)

116v: bene agentibus in lineis divisis

116v: monstraret (l. t post suprascr.)

116v: timeret (l. t post inserta)

116v: amaret (l. t post inserta)

116v: pensaret (l.t post suprascr.)

116v: deest

116v: seruitutem

117r: auctentum sed l. c partim del.

117r: sedet prona

117r: familiarem et extremum

117r: gratia

117v: Disrupisti

$117 \mathrm{v}$ : uirtutis eterne (inter haec verba del. ut videtur et)

118r: salutatis

118r: imponitur pelago (inter haec verba vacuum per Karwasińska indicatum)

118r: et si

$118 \mathrm{v}$ : ransiens (vacuum pro l. t scribenda)

$118 \mathrm{v}$ : stetit ibi sabbato

$118 \mathrm{v}$ : est et ut

118v: Ex timplo

$118 \mathrm{v}$ : dns cum signo abbrev.

119r: minhi (sic)

119r: am (ut videtur in spe initialis $l$. i adscribendae)

119v: uitamur (sic)

119v: Ottone (l. e corr. ex i)

119v: sexta 


\title{
Fifteenth-century manuscript of the Vita sancti Adalberti prior from the collection of the monastic library at Herzogenburg (with an annex concerning certain readings of Codex Klosterneuburg, Stiftsbibliothek 707)
}

\begin{abstract}
Summary: The last section of a collective codex (inventory no. 57) kept in the library of the Canons Regular Priory in the Lower Austrian locality of Herzogenburg contains a small legendarium in the fifteenth-century handwriting by a single scribe. The legendarium is composed of more than ten hagiographic works, which include (fols. 235v-244v) a copy of a so-called imperial ("A") edition of the oldest life of St. Wojciech (Adalbert). This manuscript had not been taken into consideration in heretofore research dealing with the history of the text. The hagiographic collection from the codex in question was written in 1430 or somewhat later, as it follows from an annotation made by the scribe, Erhart of Weitra, probably a lay clergyman attested in the 1420s. The detailed motives of embarking upon this task, just as the original purpose of the collection, remain unknown. Nor are we familiar with the circumstances in which it found itself in Herzogenburg. A comparison of the Herzogenburg copy of Vita prior s. Adalberti with other manuscripts of this work makes it possible to ascertain that the sole prototype of the copy executed by Erhart was the manuscript preserved up to this day and known to researchers (Klosterneuburg, Stiftsbibliothek, cod. 707, fols. 107r-119v). The article's appendices collate characteristic readings of the Herzogenburg copy of Vita prior and those distinguishing it from the Klosterneuburg version. The author has also added supplements and corrected certain information about the readings of the latter manuscript offered in the edition by Jadwiga Karwasińska.
\end{abstract}

Nota o Autorze: Szymon Wieczorek, dr, mediewista, zajmuje się historią pełnego średniowiecza (IX-XII w.), prowadzi badania nad umysłowością i religijnością łacińskiej Europy, badania źródłoznawcze i historyczno-literackie ówczesnych źródeł narracyjnych, zwłaszcza hagiograficznych, pracuje w Zakładzie Archiwistyki i Nauk Pomocniczych Historii Instytutu Historii Uniwersytetu Rzeszowskiego.

Author: Szymon Wieczorek, PhD, mediaevalist, deals with the history of the High Middle Ages (ninth-twelfth century), studies the intellectual and religious life of Latin Europe, carrying out basic source research and the historical-literary analyses of contemporary narrative sources, in particular hagiography; works at the Department of Archival Studies and Auxiliary Sciences of History in the Institute of History of the University of Rzeszów.

Instytut Historii

Uniwersytet Rzeszowski

al. Rejtana $16 \mathrm{C}$

35-959 Rzeszów

e-mail: embriko@wp.pl

\section{Bibliografia}

\section{Źródla, inwentarze, katalogi}

Bibliotheca hagiographica latina antiquae et mediae aetatis, t. 1-2, wyd. Socii Bollandiani, Bruxellis 1898-1901, Novum Supplementum, wyd. H. Fros, Bruxelles 1986

Hoffmann J., Vita Adalberti. Früheste Textüberlieferungen der Lebensgeschichte Adalberts von Prag, Essen 2005

Inventar der mittelalterlichen Handschriften des Benediktinerstiftes Seitenstetten, oprac. Ch. Glaßner, Wien 2005, $<$ www.ksbm.oeaw.ac.at/seit/inv/seitenstetten_inventar.pdf> [dostęp: 30.01.2016]

Katalog der lateinischen Handschriften der Bayerischen Staatsbibliothek München. Die Handschriften aus Augsburger Bibliotheken, t. 1: Stadtbibliothek Clm 3501-3661, oprac. E. Rauner, wstęp B. Gullath, Wiesbaden 2007

Katzenschlager W., Archivbericht, Weitra 2010, <http://www.weitra.gv.at/fileadmin/Ankuendigungen/Ankuendigungen_2012/Inventar_Stadtarchiv.pdf> [dostęp: 3.02.2016]

Kurzinventar der illuminierten Handschriften bis 1600 und der Inkunabeln in der Bibliothek des Augustiner-Chorherrenstiftes Herzogenburg in Niederösterreich, Version 1a (August 2009), oprac. A. Tif, M. Roland, M. Theisen, A. Haidinger, <http://www.univie.ac.at/paecht-archiv-wien/ki/hzbg/hzbg_hss_webbilder/index hzbg_hss_1_bis_89.html\#cod_> [dostęp: 28.12.2015]

Lackner F., Datierte Handschriften in niederösterreichischen Archiven und Bibliotheken bis zum Jahre 1600, Katalog der datierten Handschriften in lateinischer Schrift in Österreich, t. 8, Wien 1988 
The Life of Saint Adalbert Bishop of Prague and Martyr, wyd. i thum. C. Gaşpar, w: Vitae sanctorum aetatis conversionis Europae Centralis (saec. X-XI) / Saints of the Christianization Age of Central Europe (Tenth-Eleventh Centuries), red. G. Klaniczay, Budapest-New York 2013, s. 77-182

Die Matrikel der Universität Wien, t. 1, Quellen zur Geschichte der Universität Wien, Graz-Köln 1956

Mayo H., Descriptive Inventories of Manuscripts Microfilmed for the Hill Monastic Manuscript Library. Austrian Libraries, t. 3: Herzogenburg, Collegeville (Minnesota) 1985

Pfeiffer H., Černík B., Catalogus codicum manu scriptorum, qui in bibliotheca Canonicorum Regularium s. Augustini Claustroneoburgi asservantur, Klosterneunburg b.d.w. [rkps], <http://manuscripta.at/_scripts/php/newWin4msDescription.php?ID=914> [dostęp: 20.01.2016]

S. Adalberti Pragensis episcopi et martyris vita prior, wyd. J. Karwasińska, w: MPH s.n., t. 4, cz. 1, Warszawa 1962

Wiener Artistenregister 1416-1555, oprac. T. Maisel, I. Matschinegg, A. Bracher, Wien 2007, <https://phaidra. univie.ac.at/view/o:217> [dostęp: 21.04.2016]

Wiener Ratsurteile des Spätmittelalters, wyd. H. Demelius, Wien-Köln-Graz 1980

Winner G., Katalog der Handschriften der Stiftsbibliothek Herzogenburg, St. Pölten 1978 [mszp.], <http:// manuscripta.at/diglit/winner_1978_1/> [dostęp: 30.01.2016]

\section{Opracowania}

900 Jahre Stift Herzogenburg. Aufbrüche - Umbrüche - Kontinuität. Tagungsband zum wissenschaftlichen Symposium vom 22.-24. September 2011, red. G. Katzler, V. Zimmerl-Panagl, Innsbruck 2013

Blume D., Bern von Reichenau (1008-1048): Abt, Gelehrter, Biograph. Ein Lebensbild mit Werkverzeichnis sowie Edition und Übersetzung von Berns 'Vita S. Uodalrici', Vorträge und Forschungen. Sonderband, t. 52, Ostfildern 2008

Brucher G., St. Wolfgang bei Weitra, w: Gotik, red. G. Brucher, Geschichte der bildenden Kunst in Österreich, t. 2, München-London-New York 2000, s. 292 n.

Cerny H., Beiträge zur Geschichte der Wissenschaftspflege des Stiftes Seitenstetten im Mittelalter, „Studien und Mitteilungen zur Geschichte des Benediktinerordens und seiner Zweige”, 78, 1967, s. 68-143

Derolez A., The Palaeography of Gothic Manuscript Books from the Twelfth to the Early Sixteenth Century, Cambridge-New York 2003

Kunzelmann A., Geschichte der deutschen Augustiner-Eremiten, cz. 3: Die bayerische Provinz bis zum Ende des Mittelalters, Würzburg 1972

Lanéry C., La Passion de Théodora et Didyme. Édition des traductions latines BHL 8072 et 8073, „Analecta Bollandiana", 122, 2004, s. 5-50

Lind K., Über die drei mittelalterlichen Kirchen der Minoriten, Augustiner und Carmeliten in der Stadt Wien, „Berichte und Mittheilungen des Alterthums-Vereines zu Wien”, 5, 1861, s. 127-176

Lohr Ch.H., Medieval Latin Aristotle Commentaries. Supplementary Authors, „Traditio”, 30, 1974, s. 119-144

Markowski M., Abhandlungen zur Logik an der Universität Wien in den Jahren 1365-1500, „Studia Mediewistyczne", 22, 1983, nr 1, s. 53-77

Markowski M., Wiedeńskie komentarze do dziet Arystotelesa w rękopisie 749 biblioteki benedyktynów w Admont, „Studia Antyczne i Mediewistyczne”, 36, 2003, s. 171-177

Müller H.Fr.X., Die kirchenrechtlichen Verhältnisse des Augustiner-Chorherrenstiftes Waldhausen im Spätmittelalter. Seine Anfänge und sein Pfarrnetz, „Jahrbuch des Oberösterreichischen Musealvereines”, 113, 1968, nr 1 , s. $73-108$

Payrich W., Herzogenburg, w: Die bestehenden Stifte der Augustiner-Chorherren in Österreich, Südtirol und Polen, red. F. Röhrig, Klosterneuburg-Wien 1997, s. 29-98

Rennhofer F., Die Augustiner-Eremiten in Wien. Ein Beitrag zur Kulturgeschichte Wiens, Würzburg 1956

Riain D.Ó., The „Magnum Legendarium Austriacum”. A New Investigation of One of Medieval Europe's Richest Hagiographical Collections, „Analecta Bollandiana”, 133, 2015, s. 87-165

Sosnowski M., Hagiografia doby chrystianizacji w nowej odstonie, Kwart. Hist., 122, 2015, z. 4, s. 877-901

Stelzer W., 'Vita Maximiliani', w: Die deutsche Literatur des Mittelalters. Verfasserlexikon, t. 10, wyd. 2, Berlin-New York 1999, kol. 443-448

Stöller F., Österreich im Kriege gegen die Hussiten (1420-1436), „Jahrbuch für Landeskunde von Niederösterreich", NF, 22, 1929, s. 1-87

Wieczorek S., „Bona stultitia”. O znaczeniu paradoksów retorycznych $w$ najstarszym żywocie św. Wojciecha, Kwart. Hist., 122, 2015, z. 3, s. 417-455 